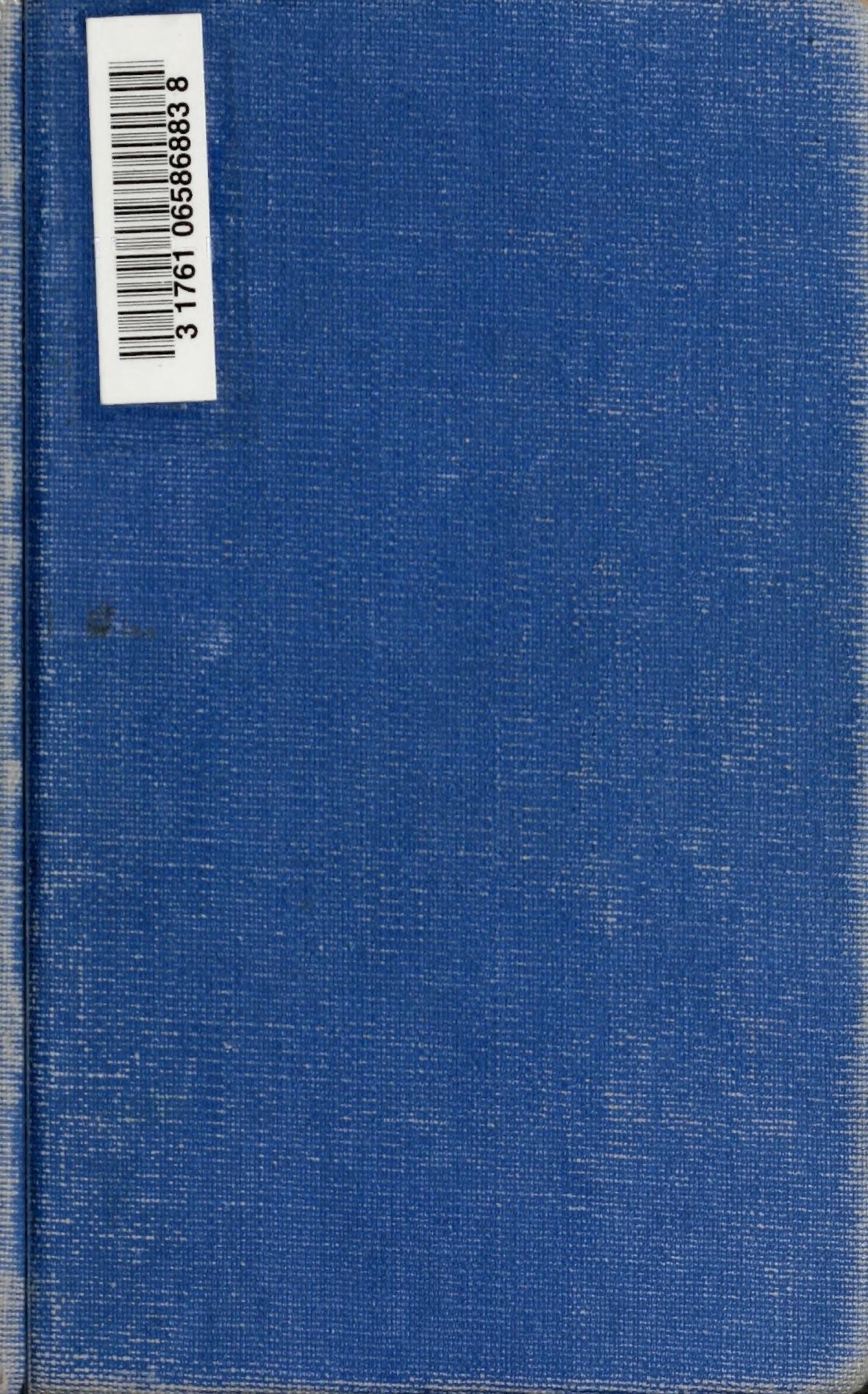



Digitized by the Internet Archive in 2007 with funding from Microsoft Corporation 



\section{DARWINISM AND POLITICS.}

BY

D A VID G. R I T C H I E, M. A.,

Fellow and Tutor of Jesus College, Oxford.

SECOND EDITION, WITH TWO ADDITIONAL ESSAYS ON HUMAN EVOLUTION.

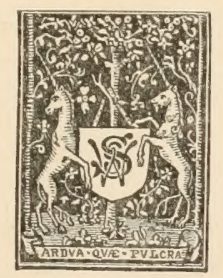

LONDON :

SWAN SONNENSCHEIN \& CO., PATERNOSTER SQUARE.

I 80 I 


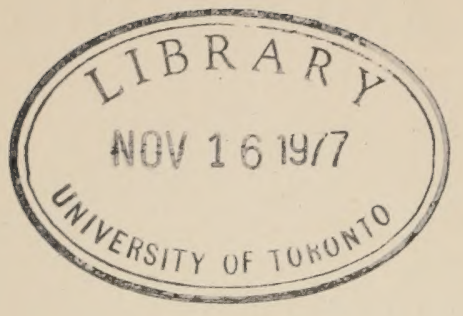

Butler \& TANNer,

The Selwood Printing Works,

Frome, and London. 


\section{PREFACE TO THE SECOND EDITION.}

T may perhaps obviate some objections if I state 1 here in one sentence what my main thesis is, although indeed I should have thought that it admitted of no misunderstanding. In the essay entitled Darwinism and Politics, now reprinted with a few verbal alterations, I seek to prove that The theory of Natural Selection (in the form in which alone it can properly be applied to human sociefy) lends no support to the political dogma of Laissez faire. The second and third essays, which are now added to the original essay, deal with the parenthetic clause, and attempt to answer the question: In what form, if can the theory of Natural Selection properly he apptied to the intellectual, moral and social development of man? The second essay is a criticism of the last chapter of Mr. A. R. Wallace's Darwinism, and has already appeared in the Westminster Review. The third has been suggested by some "Anti-evolutionist" objections of Dr. Emil Reich. It is, I think, always convenient, and especially in a brief treatment of a subject, to have definite objections to deal with and to use a dialectic method instead of the formal exposition more appropriate to an elaborate and systematic treatise.

A critic in the Academy complains that he cannot grasp the exact object of my little book. Well, I do 
not think I really can do anything more to help him or any one else who feels a similar difficulty. He also complains of my using the term "Darwinism" for the doctrine of Evolution. I have used the term "Darwinism" not, as he suggests, in imitation of the German habit, but simply because I mean it. I am dealing with the scientific theory of Natural Selection, and not with all those metaphysical hypotheses which go under the name of Evolution. On this matter a little has been said at the beginning of the second essay.

My friend, Mr. E. B. Poulton (to whom, more than to any man or book I am indebted for my biological premises, though of course I must not hold him responsible for all the sociological and practical conclusions I have ventured to draw), has just called my attention to a little work by Mr. W. Platt Ball, entitled, Are the Effects of Use and Disuse inherited? (London, I890). Mr. Ball argues with great force against Mr. Herbert Spencer and against the Lamarckianism surviving in Darwin, that the theory of "Use-inheritance" (i.e. the direct inheritance of the effects of use and disuse in kind) is "unnecessary, unproven and improbable:" and he draws the important practical inference that for the improvement of human society reliance on use-inheritance is misplaced. With all this I entirely agree. But when Mr. Ball goes on to treat his arguments against private philanthropy as if they were also valid again'st systematic action on the part of the State, I must dissent in the strongest manner. Let me quote a few sentences from the "Preface" and the "Conclusion" of Mr. Ball's work :- 
"Civilisation largely sets aside the harsh but ultimately salutary action of the great law of Natural Selection without providing an efficient substitute for preventing cleseneratcy. The substitute on which moralists and legislators rely-if they think on the matter at all-is the cumulative inheritance of the beneficial effects of elucition, training. habits, institutions and so forth-the inheritance, in short, of acquired characters, or of the effects of use and disuse" (p. vii).

"The selective influences by which our present high level has been reached and maintained may well be modified [How much does Mr. Ball mean by that?], but they must not be abandoned or reversed in the rash expertation that state educat tion, or State feeding of children, or State housing of the poor, or any amount of State socialism or public or private philanthropy will prove permanently satisfactory substitutes. If ruinous deterioration and other more immediate evils are to be avoided, the race must still be to the swift and the battle to the strong. The healthy Individualism so earnestly championed by Mr. Spencer must be allowed free play" (p. I 55 ).

What I have said on Pp. 53, 5t anticipates the way in which I should meet this argument. Just because it is "not proven" that acquired characteristics are transmitted, we cannot trust for the improvement of the race to the moralisation of stray individuals now (however desirable and necessary that is in itself): we must reform institutions so that the new individuals shal! be born into healthy surroundings. The training process has always to be performed afresh. In the course of his arouments against the Lamarckian doctrine, Mr. Ball has shown how much can be done by education and imitation, apart from heredity, even among the social insects, how very much more among human beings. Of this fact we must make all the use we can. Of course it will make a great difference what kind of natures we have for the very best institutions to work upon. But to get the best natures, can we trust, as Mr. Ball does, 
to "open competition"? It is rather late in the day to talk of "open competition" as a panacea for all social ills. Those who really wish to trust to Natural Selection in its original form, which operates by the cxtinction of the unfit, must be ready to strip the human race of all the painfully won results of civilisation and to return, first to barbarism, and then to a sencral scramble for nuts in the primeval forest-out of which scramble, however, Natural Selection, in its gradually ascending forms, would some day build up civilised society again. Open competition might give results of some value if every one were to start fair, run on his own legs and carry equal weicht; but open competition between one man in a sack with a bundle on his shoulders, another on a good horse, and a third in an express train is a farce, and a somewhat cruel one, when the race is being run for dear life. Yet that is what our would-be evolutionary politicians seriously propose; and think themselves "scientific" all the while! Natural Selection must mean something else than this before we apply it in practical politics.

On the other hand, for Artificial Selection (which Mr. Ball suggests as an alternative) a great deal may be said: but the person who says it must be prepared to be laughed at, even if he escapes the experience of secing "respectable persons taking off their coats and making for him with anything that comes handy."

December, 1890.

D. G. R. 


\section{CONTENTS.}

PREFACE . . . . . . . . . .

DARIVINISM AND POLITICS.

1. "The Struggle for Existence" in Malthus and, Darwin: How the idea is applied to Politics:

Is the Struggle "beneficent?" . . . . I

2. The Evolution Theory as applied to Ituman Suciety" by Darwin, Strauss, Mr. H. Spencer, Sir H. Maine, Mr. E. Clodd . . . . . . 6

(3.) Imbiguity of the phrase "Survival of the Fittest:". Complexity of Social Evolution . . . . 12

4. Does the doctrine of IIeredity support Aristocracy? I?

I Joes the Evolution Theory support Laissez faire? Struggle between ideas for survival : Consciousness as a factor in Evolution: Testimony of Prof. Huxley and Strauss: Ambiguity of "Nature: "Conscious "Variations" . . . . 20

5. Why fix ideas in institutions? Custom-its use and abuse : Institutions and "the social factor" generally are neglected in the popular acceptation of the doctrine of Heredity: Mr. Galton's views considered: Darwin's own opinion . . 37

$\$ 7$. The Law of Social Progress . . . . . . 55

S. Applications :

(I) The Labour Question . . . . . 58

(2) The Position of Women : . . . 62

(3) The Population Question . . . . 76 
NATURAL SElEction AND THE SPIRITUAL World.

§ 1. Darwinism complete and incomplete: Mr. A. R. Wallace's exclusive advocacy of Natural Selection and desertion of it . . . . . . 87

2. The Evolution of Morality and what it implies: Utilitarianism vindicated and corrected . . 96

3. Intellectual Evolution: Mathematics, music, metaphysics, wit . . . . . . . . 107

$\$$ 4. Conclusion : the true "spiritual world" . . . II 4

Natural Selection and the History of InstituTIONS.

\$. Historian versul Evolutionist . . . . . II9

\$2. "Variation" in Sociology . . . . . I I I

3. "Heredity" : "Survivals" . . . . . I3I

§ 4. "Struggle for Existence" . . . . . . I 139 
I.

\section{DARIVINISM AND POLITICS.}

Sัr. "THE STRUGGLE FOR EXISTENCE."

CHARLES DARIVIN himself has told us $^{1}$ that it was Malthus's Essay on Population which suggested to him the theory of Natural Selection. The constant tendency of population to outrun the means of subsistence and the consequent struggle for existence were ideas that only needed to be extended from human beings to the whole realm of organic nature in order to explain why certain inherited variations become fixed as the characteristics of definite types or specics. Thus an economic treatise suggested the answer to the great biological problem; and it is therefore fitting that the biological formule should, in their turn, be applied to the explanation of social

1 Life and Letters of Charles Dancin, I. p. 83. Cp. Letter to Haeckel, quoted by Grant Allen, Darain, p. 67 . 
conditions. It is felt, rightly enough, that the problems of human society cannot be fairly studied, if we clo not make use of all the light to be found in the scientific investigation of nature; and the conception of the strugsle for existence comes back to the explanation of human society with all the added force of its triumph in the solution of the greatest question with which natural science has hithertosucessfully dealt. Our sociologists look back with contempt on older phrases, such as "Social Contract" or "Natural Rights," and think that they have gained, not only a more accurate view of what is, but a rule available in practical ethics and politics. Evolution has become not merely a theory but a creesl, not merely a conception by which to understand the miverse, but a guide to direct us how to order our lives.

- The phrase "struggle for existence," as it came from the pages of Malthus, had a dreary cnough sound; but, when this struggle for existence is shown to lead to the "survival of the fittest," and when it is seen to' be the explanation of all the marvellous adaptations and of all the beauty of the living things in the world, it secms to gain a force and even a 
sanctity which makes it a very formidable opponent to have to reckon with in any political or ethical controversy. It is easy to see how the evolutionary watch-word can be applied. In Malthus the idea of struggle for existence was a very uncomfortable one; but, when it comes back to economics after passing through biology, it makes a very comfortable doctrine indeed for all those who are quite satisfied with things as they are. The support of scientific opinion can be plausibly claimed for the lefence of the inequalities in the social orranism; these inequalities, it can be urged, are only part of what exist inevitably throughout the physical world. The creed of Liberty, Equality, I raternity can be discarded as a metaphysical fiction of the unscientific eighteenth century: The aspirations of socialism can be put aside as the foolish denial of the everlasting economic competition which is sanctioned by nature as only one phase of the general struggle for existence.

Let us suppose, for a moment, that our biological politicians are correct in their view of social evolution : they ought, at least, to cease talking to us of "the beneficent working of the 
survival of the fittest," or "the beneficent private war, which makes one man strive to climb on the shoulders of another." "This talk of "beneficence" is itself but a survival, not of the fittest, but of the "theological" belief in a God who wills the happiness of his creatures-the attenuated creed of the English Deists-or of the "metaphysical" belief in a Nature which. * if only left to itself, leads to better results than can be secured by any interference of man. That was the type of thinking in the days of Rousseau and Adam Smith: and our erolutionary enthusiasts, when they talk of beneficence, are, after all, but repeating the creed of the despised eighteenth century, or else they are only disguising under a hypocritical phrase the triumphant crowing of the successful fighting-cock, aloft on his own dung-heap, while his vanquished opponent slinks away battered and bleeding. From natural selection there have resulted wonderful adaptations, but how much of suffering by the way, how much of horrid cruelty in these adaptations themselves? The great Darwin himself speaks in a very different

1 II. Spencer, The Man rersus the State, p. 69; Maine. Popular Government, p. 5 o. 
tone from that of his jubilant disciples. Things do not look so clear to hin He marvels at this wonderful universe, and especially at the nature of man, but "I cannot see," he say's, "as plainly as others do, and as I should wish to do, evidence of design and beneficence on all sides of us. There seems to me too much misery in the world."

". If plagues or carthquakes break not Heav'n's design, Why then a Borgia or a Catiline?"

asks Pope with the contented optimism of his easy-going age. And if the fratricidal morality of the bee-hive and the fiendish cumning of the Spher are to be admired, is there not a similar justification for military despotism and tyrannical cruelty, or for the ingenious device of the sweating system?

"We dined, as a rule, on each other.

What matter? the toughest survived." ?

This is a sufficient morality in the mesozoic epoch for the ichthyosaurus, to whom the senti-

1 From a letter to Dr. Asa Gray, in Life and Letters, II. 312 .

"May Kendall, Driams to Sell, "Ballad of the Ichthyosaurus." 
ment is ascribed by the poet; and it is a convenient morality for some human animals in London to-day. Admirable, doubtless-this scheme of salvation for the elect by the damnation of the vast majority; but, pray, do not let us hear anything more about its "beneficence."

\section{\$2. THE EVOLUTION THEORY APPLIED TO} HUMAN SOCIETY.

I am not speaking at random about these ethical applications of the conception of struggle for existence. Darwin himself, as always, is most cautious and guarded in his reference to any thing that ties outside his own special sphere of observation. He looks forward to the elimination of the lower races by the higher civilised races throughout the world. ${ }^{1} \mathrm{He}$ points out how "a struggle for existence consequent on his rapid multiplication," has adranced man to his present high condition; " and, if he is to advance still higher, it is to be fearcd that he must remain subject to a severe strugerle. Otherwise he would sink into indolence, and the more gifted men would not be more successful in the battle of life than the

1 Jife and Letters, I. $3 \mathrm{I} 6$. 
less gifted." This, doubtless, includes the otd objection which Iristotle brought against Plato's communism, that man needs a stimulus to exertion and industry: But there is no jubilation, no exaltation of a naturil law into an ethical ideal. And let us note how Darwin modifies this very statement in the words that follow :-

"Important as the struggle for existence has been and even still is, y'et as far as the highest part of man's nature is concerned there are other agencies more important. For the moral qualities are advanced, either directly or indirectly, much more through the effects of habit, the reasoning powers, instruction, religion, etc., than through natural selection; though to this latter agency may be safely attributed the social instincts which afforded the basis for the development of the moral sense.'

Darwin disclaims the connexion, which had been alleged in Germany, between the doctrine of natural selection and socialism.2 He sees clearly enough that his theory gives a primat facic support not to socialism, but to industrial competition. Yet he is anused at the idea of The Origin of Specie's having turned Sir Joseph

1 Descent of Man, p. 6r8.

2 Life and Letters, III. 237. 
"Hooker into "a jolly old Tory." " "Primogeniture," he says, "is dreadfully opposed to selection: suppose the first-born bull was necessarily" made by each farmer the begretter of his stock!" Still, he admits that English peers have an advantage in the selection of "beautiful and charming women out of the lower ranks," and thus get some benefit from the principle. In answering Mr. Galton's questions, Darwin describes his own politics as "Liberal or Radical :" - and this was in 1873 , by which time Radicalism was no longer bound to out-and-out laissez faire.

Evolution, as applied to the whole of the universe, means a great deal more than the principle of natural selection. In the wider sense it is professedly applied to the guidance of life by Strauss in his famous book, The Old Faith and the Ncai, where military conquest and social inequalities are expressly defended as right, lecause natural ; and nothing but contempt is reserved for those who venture to hope for the abolition of war, who look beyond the limits of the nation or who dream of a

1 Life and Letters, II. $38_{5}$.

Ib. III. 178 . 
better social order.' It misht be objected that in these passases we do not hear the voice of (ierman science and philosophy, but of that reactionary military spirit which has infected the new German nation; and I think it could be shown that such sentiments are inconsistent with admissions that Strauss himself makes, although he and most German saidunts with him belicve that they are a necessary consequence of the Evolutionist creed.

Let us turn, however, to our English philosopher who is always protesting ayainst everything that can on any pretext be ascribed to the revived militancy of the present day. In the name of Evolution and on behalf of the survival of the fittest Mr. Herbert Spencer cries out against "The Sins of Legislators" in interfering with the beneficent operation of the pitiless discipline which kills off the unsuccessful members of society, and against "The Coming Slavery," which he supposes would result from socialistic attempts to diminish the misery of the world. ${ }^{2}$ Now, just as in Strauss's case

1 See esp. secs. $78,79,82,83,84$ in German (ed. 8 . $1875)=$ secs. $74,75,78,79$, 80 in Eng. Tr. (ed. 3. 1874).

2 See The Man 2 . the State, esp. the two essays named. 
the military spirit, so in Spencer's the oldfashioned individualistic radicalism of his early clays might be assigned as the true source of such opinions; but there can be no doubt that the formulxe of Erolution do supply an apparent justification to the defenders of unrestricted laisse faire and to the champions, more or less consistent and thorough-roing, of existing inequalities of race, class and sex, and a plausible weapon of attack against those who look to something better than slavery or competition as the basis of human socicty. Thus Spencer rejoices over the Liberty and Property Defence League, "largely consisting of Conservatives," and the late Sir Henry Maine in the congenial pages of the Quartcrly Ricicw rejoiced over Mr. Herbert Spencer and glorified "the beneficent private war" of economical competition, which he considered the only alternative to "the daily task, enforced by the prison and the scourge." ".So far," he says, "as we have any experience to teach us, we are driven to the conclusion that every society of men must

\section{The Man versus the State, p. I 7.}

2 Republished in Iopular Gorermment. See pp. 49, 50, 52. 
aclopt one system or the other, or it will pass through penury to starvation."

Even those who are more full of hope: for the future and more full of sympathy for human beings, are apt to adopt a similar mode of speaking. Thus, in his interesting little book, The Story of Cration, Mr. Eilward Cindel, though he looks forward to "a sroal, where might shall be subdued by right," yet speaks as follows :

"When the weeding process has lone its utmust, there remains a sharp struggle for life between the survivors. Man's normal state is therefore one of conflict; further hack than we can trace, it impelled the defenceless bipeds from whom he spreng to unity, and the more so berause of their relative inferiority in physique to many other animals. 'T'he range of that unity continued narrow long after he had sained lordship over the brute; outside the small combinations for securing the primal needs of life the struggle was ferocious, and, under one form or another, rages along the line to this day. 'There is no discharge in that war.' It may change its tactics and its weapons: among advanced nations the military method may be more or less superseded ly the industrial, a man may be mercilessly starved instead of being mercilessly slain; but be it war of camp or markets, the ultimate appeal is to force of brain or muscle, and -the hardiest or craftiest win. In some respects the struggle is waged more fiercely than in olden times, while it is unredeemed by any element of chivalry." (pl). 2 r I, 2r 2.) 
It is thus of the extremest practical importance to sec what is the real bearing of Evolution on social problems. ITe must examine the relation between biological liaws and social faiths and hopes, if we would make our opinions self-consistent; and self-consistency is the negative test of truth. Such an examination is especially incumbent on those who profess to keep their minds open to all that science can teach, and at the same time to have at heart the cause of social reformation. IVe ought to have: a reason for the faith that is in us. To test our scattered opinions and beliefs by bringing them together is the main function of a sound philosophy.

\section{S3. "SURVIVAL OF THE FITTEST."}

The phrase "survival of the fittest" is very apt to mislead, for it suggests the fittest or best in every sense or in the highest sense, whereas. it only means, as Prof. Huxley has pointed out, those "best fitted to cope with their gircumstances" in order to survive and transmit

1 Art. on "The Struggle for Existence," in Nincticntic Century for Feb., I888, p. I65. 
offspring. Now when we come to consider society, we have to deal with a very complex set of phenomena, and what is fittest in one aspect may not be fittest in another. But natural selection implies no further morality than "Nothing succeeds like success." If the struggle for food and mates be carried on on its lowest terms, the strongest and the strongest only would be selected. But cunning can do a great deal against strength. Now we cannot be sure that a good combination of strength and cunning will be selected : strength in some cases, cunning in others - this is what we find if we compare different species of animals and different races of men. Again, the strongest and largest and in many ways finest animals are not necessarily those most capable of adapting thenselves to changed circumstances. The insignificant may more easily find food and escape enemies. IVe cannot be sure that Evolution will always lead to what we should regard as the greatest perfection of any species. Degeneration enters in as well as promress. The latest theory about the Aryan race makes it come from the north of Europe, conquer the feebler races of the south, and, having proved 
its fitness in this way, prove its unfitness in another by being less capable of surviving in a warm climate than they; so that an Aryan language may be spoken, where there remains little or no Aryan blood. ${ }^{1}$ Are we entitled to maintain, with regard to human races and human individuals, that the fittest always survive, except in the sense in which the proposition is the truism, that those survive who are most capable of surviving?

Further, we must emphasize the fact that the strus.r. goes on not merely between individual and individual, but between race and race. The struggle among plants and the lower animals is mainly between members of the same species; and the individual competition between human beings, which is so much admired by Mr. Herbert Spencer, is of this primitive kind. When we come to the struggle: between kinds, it is to be noticed that it is fiercest between allied kinds; and so, as has been printed out, the economic struggle between Great Britain and the United States is fiercer than elsewhere between nations. But,

See Art. by Prof. Rhys on "Race Theories and European Prolitics," in Niz' P'rinccton R'ceriezi', Jan., ISSS. 
so soon as we pass to the struggrle between race and race, we find new elements coming in. The race which is fittest to survive, i.c. most capable of surviving; will survive; but it does not therefore follow that the individuals thereby preserved will be fittest, either in the sense of being those who in a struggle between individual and individual would have survived, or in the sense of being those whom we should regard as the finest specimens of their kind. $A$ race or a nation may succeed by crushing out the chances of the great majority of its individual members. The cruel polity of the bees, the slave-holding propensities of certain species of ants have their analogues in human societies. The success of Sparta in the Hellenic world was obtained at the cost of a frightful oppression of her subject classes and with the result that Sparta never produced one really great man. How much more does the world owe to Athens which failed, than to Sparta which succeeded in the physical struggle for existence?

But human beings are not merely, like plants and animals, grouped into natural species or varieties. They have come to group them- 
selves in very various ways. Thus an individual may, conccivably, belong by descent to one group, by political allegiance to another, by language, and all that language carries with it of tradition and culture, to a third, by religion to a fourth, by occupation to a fifththough in most cases two or more of these will coincide. Now between each of these groups and similar groups there are, as the doctrine of Evolution teaches us if we need to be taught, struggles constantly proceeding. Race struggles with race, nation with nation, langruage with language, religion with religion, and social castes based on occupation and on economic status struggle with one another for pre-eminence, apart from the struggle going on between individuals and groups of individuals within each of them. Now, if in each of these cases the struggle were not complicated by the other struggles, we might contentedly assert that natural sclection leads to the fittest always succeeding. But a defeated and subject race may impose its language, its civilisation, or its religion upon its conquerors; and the apparent failure of a race or a nation does not entitle us at once to pronounce it inferior or less fit, be- 
cause its failure in warfare may be the prelude to a greater and more lasting success in peace.

\$4. DOES THE DOCTRINE OF HEREDITY SUPPORT ARISTOCRACY?

On the other hand, it is easy to see how the pre-eminence of a caste, based either on race or on occupation, may be maintained at the cost of the physical and intellectual advance of its members. Where noble may marry only noble and where marriages are "arranged," as the phrase runs (more truthful than most of those current in the fashionable world), the interests of the health and of the intelligence of the race may be sacriliced to the maintenance of a closely coherent class with large estates and social predominance. Such a type of nobility will in the long run inevitably lose power owing to its own internal decay through continued intermarriage and lack of new blood. Yet superficially plausible arguments from the doctrine of heredity are occasionally brought forward in its favour. The democrat is often told that he is very unscientific; but the evolutionist, who points to the aristocratic preferences of history, errs greatly if he thinks the 
undoubted pre-eminence of a few great individuals and even of a few famous families any sound argument in favour of a hereditary aristocratic caste. Darwin, as we have already seen, admits that the nobility in this country have a certain advantage in being able to select their wives more freely than most other men: yet, allowing their superiority in this matter to the nobilities of other countries and rejoicing that the institution of the peerage has saved us from the worse calamity of a "nobility" in the proper sense, we may be permitted to regret that these highly privileged persons, the peers and the peers' eldest sons, do not always think sufficiently of their responsibility to the future in the selection of their mates. Darwin, as we have also seen, inveighs against the folly of primogeniture: so that, after all, even the English nobility do not get much countenance from the theory of natural selection. It is strange to find the doctrine of heredity invoked by the defenders of the House of Lords: one would suspect that they have never looked into Mr. Galton's interesting book. It is instructive to notice the way in which half-understood scientific 
theories are misapplied to practical matters. Mr. Galton declares most emphatically that he looks upon the peerage "as a disastrous institution, owing to its destructive effects on our valuable races." If an eminent man is elevated to the House of Lords, his eldest son is tempted to marry a wealthy heiress, in order to keep up the show required of a hereditary legislator; but wealthy heiresses usually tend to be sterile, being the last representatives of dwindling families. On the other hand, owing to the custom of primogeniture, the younger sons are induced to remain unmarried: and thus the peerage appears to be an ingenious device for hindering the propagation of talent. ${ }^{1}$ Further Mr. Galton shows clearly enough the absurdity of expecting to find ability transmitted through a long line of descent: the older a man's family, therefore, the less likely is he to have inherited any of the ability of its founder. I suppose there is still a pious Conservative superstition that "our old nobility" can boast of its "Norman blood"-a belief which a critical examination of a recent copy of the Pecrage would do a good deal to weaken

1 See Galton's Hereditary Genius, p. I40. 
But even supposing the Norman blood were there, does it follow that it is now particularly worth having? "It is curious to remark," says Mr. Galton, "how unimportant to modern civilisation has become the once famous and thoroughbred looking Norman. The type of his features, which is, probably, in some degree correlated with his peculiar form of adventurous disposition, is no longer characteristic of our rulers, and is rarely found among celebrities of the present day; it is more often met with among the undistinguished members of highly born families, and especially among the less conspicuous officers of the army." I I have not yet raised the question as to what kind of characteristics can be transmitted from generation to generation and in what way: I have only tried to show that the scientific doctrine of heredity is a very treacherous ally of the defenders of aristocratic privilege.

\$5. DOES THE EVOLUTION THEORI' SCI'PORT "LAISSE" FAIRE"?

The doctrine of Evolution gives little support to the aristocratic Conservative. It may seem

1 Hereditary Genius, p. 348 . 
to give more to the "laisser farre" Radical. The evolutionist politician is more likely to adopt the view that in the interests of the race we ought to remove every artificial restriction on the operation of natural and sexual selection. But the difficulty is-where are we to find a line between "natural " and "artificial," if all the phenomena of socicty are, as the evolutionist is bound to hold. subject to the same laws of nature? If we are content to remove only some artificial restrictions, on what principle can we justify ourselves? If we are to remove every artificial restriction that hampers the struggle for existence, are we not going back to Rousseau's "State of Nature," the primitive, uncivilised, pre-social condition of mankind? If we expect the "State of Nature" to be better than the present condition, which is one of at least mitigated or inconsistent anarchy, are we not falling back into the "metaphysical" conception of Nature and ignoring the scientific conception of society? The "State of Nature," i.e.the unsocial state, is more correctly described by Hobbes as "the war of all against all." On the other hand, when we find the more tenderhearted preacher of evolutionist morality point- 
ing out that, though the physical well-being of the race may have suffered through the mitigation of the primitive struggle and the consequent preservation of weaklings, we have gained some intellectual advance through the occasional chance of a Newton and a moral advance through the cultivation of sympathy and tenderness, ${ }^{1}$ in such a position is there not some inconsistency, some sacrifice of natural selection in favour of human selection consciously or half-consciously directed to other ends than those of mere nature? Our attention is thus called to another factor in that universal strife which is the story of the universe. So soon as a sufficient social development and a sufficiently advanced type of language make it possible, there begins a competition between ideas. The age of conflict is, in Bagehot's phrase, ${ }^{2}$ succeeded by "the age of discussion," and the ideas, which rise in the minds of men with the same tendency to variation that we find throughout nature, compete with one another for sustenance and support. The conception of natural selection may be applied here also to

1 E. Clodd, Story of Creation, p. 2 I I.

2 Physics and Politics. 
explain how certain ideas come to obtain that relatively fixed and definite character which belongs, for instance, to the moral principles currently accepted within a community at any given time. Thus such ideas as patriotism, respect of human life as such, self-control in regard to the bodily appetites, have won their way so as to become factors in the struggle and to conflict with the operation of natural selection as this prevails among the mere animals. Why then may not such ideas as Equality and I raternity claim to have a fair chance in the struggle for existence? If they can win possession of more and more minds in the world, they will become actual influences on conduct and will from: being mere ideals tend to bring about their own realisation " "Opinions," said, Lord Palmerston, "are stronger than armies." One of the first conditions of any institution being altered is that people should come to imagine it as altered. The great difficulty of the reformer is to get people to exert their imagination to that extent.

Now what does all this amount to except to

${ }^{1} \mathrm{Cp}$. Fouillée, La Scichce Sociale Contemporaine, p xii., etc. 
a recognition of the difference introduced into. natural evolution by the appearance of consciousness? I shall not now attempt to work out all the philosophical implications involved in this recognition of consciousness: nor, in order to show how through consciousness man becomes free from the tyranny of nature, shall I quote the words of any one whose evidence might be suspected because he might be called a mere metaphysician. I shall quote the words of a witness whom no scientific man would rejectProfessor Huxley :-

"Society, like art, is a part of nature. But it is convenient to distinguish those parts of nature in which man plass the part of immediate cause as something apart ; and, therefore, society, like art, is usefully to be considered as distinct from nature. It is the more desirable, and even necessary, to make this distinction, since society differs from nature in having a dennite morat objeçt; whence it comes about that the course shaped by the ethical man-the member of society or citizen-necessarily runs counter to that which the nonethical man-the primitive savage, or man as a mere member of the animal kingdom-tends to adopt. The latter_fights out the struggle for existence to the bitter end, like any otheramimal; the former devotes his best energies to the object of setting limits to the struggle.

"The history of civilisation-that is of society-is the record of the attempts which the human race has made to 
escape from this position [i.e. the struggle for existence in which those who were best fitted to cope with their circumstances, but not the best in any other sense, survived]. The first men who substituted the state of mutual peace for that of mutual war, whatever the motive which impelled them to take that step, created society. Iut in establishing peace, they obviously put a limit upon the struggle for existence. Between the members of that society, at any rate, it was not to be pursued it ontrance. And of all the successive shapes which society has taken, that most nearly approaches perfection in which war of individual against individual is most strictly limited." I

Professor Iluxley then goes on to show how the struggle for existence appears in a new form through the zealous fulfilment of what we are told was the first commandment given to man"Be fruitful and multiply." But, instead of arguing, as before, that the further history of civilisation must consist in putting a limit to this new economic struggle, he avoids drawing any such inference, and very lamely concludes that we must establish technical schools. These are most desirable and necessary institutions, but they might fulfil some better purpose than what he proposes-which is simply to sharpen our claws that we may fight our neighbours

1 Art. "The Struggle for Existence," in Ninetecnth Century", Feb., I888, pp. 165 , I66. 
the more fiercely and destroy them the more successfully. Let us be grateful, however, to Professor Huxley for the scientific conclusions which he has drawn. As practical premises they will serve us for a wider syllogism than he ventures to construct. It is the same with Strauss. In spite of his excessive conservatism in practical matters, this is the way in which he formulates in general terms the "Rule of Life":

"Ever remember that thou art human, not merely a natural production; ever remember that all others are human also, and, with all individual differences, the same as thou, having the same needs and claims as thyself: this is the sum and substance of morality."

"In man Nature endeavoured not merely to exalt, but to transcend herself. He must not therefore be merely an animal repeated; he must be something more, something better."

"Man not only can and should know Nature, but rule both external Nature, so far as his powers admit, and the natural within himself." "

It is unnecessary here to raise the question how consciousness malies its appearance. It is enough that human beings are not only engaged

1 The Old Faith and the Nere. Eng. Transl. ii. pp. 54, $57,5^{8}$ (secs. $70,7 \mathbf{r}=$ secs. 74,75 in German edit. $\mathbf{r} 875$ ). 
in the struggle for existence, but know that they are so engaged, are capable of looking round on what they are doing, of reflecting, of comparing results and considering some good, some bad, some to be desired and others to be avoided. If we distinguish - as Professor I Iuxley says it is convenient to do-between man and nature, then it is of extreme importance to us to discover the natural laws which operate in society, but it does not follow that we owe them any allegiance. They are "laws" simply in the sense of being generalisations from experience of facts or hypotheses by which we find it possible to make the facts more intelligible to ourselves: and it is the merest ambiguity of language that leads to the argument that what can be called "an economic law" has any claim upon our reverence. It may tell us something convenient or something inconvenient; but of itself it is, like nature, absolutely non-moral.

On the other hand, if we use Nature (with a very big $N$ ) to include all that goes on in human society, human institutions and human ideas must be included in this conception of Nature: else the scientific sociologist is assum- 
ing a supernatural, or infranatural, region outside human society. Governments are natural products, and it is inconsistent in Mr. Herbert Spencer, while telling us that the maxim "Constitutions are not made but grow" has become a truism, to go on to blame governments simply because they "interfere" with natural laws. Why, such "interferences" would on his own principles amount to a miracle! The real and significant distinction is not that between "State-interference" and "laissc firme," but between intelligent and scientific, i.e. systematic and far-sighted State-action on the one side and that peddling kind of playing at an occasional and condescending providence in small matters, which is often much worse than doing nothing at all. The State which "protects" a few industries and doles out its alms to a multitude of paupers is only yet half conscious of its functions and may be doing unmitigated evil, except in so far as it is performing some interesting but rather cruel experiments for the benefit of sociological students. "Protection" and a bad poor-law (i.e. any mode of relief which breeds pauperism instead of diminishing it) are just the kinds of State-action which 
have brought all State-action into disrepute and make the arguments against it plausible. There are, however, many cases where the arguments against a partial State-action cease to hold against the same action if made more thoroughgoing: c.g. giving free education to some children may be objected to as pauporising; free education as the right of all would make none paupers. Yet even a partial Stateaction may often be welcomed, as a recognition that the State has duties towards its weaker members, however inefficiently it may discharge them.

The capacity for thinking constitutes man's freedom. It is by thinking alone that he can rise above the position of nature's slave. This does not amount to asserting the foolish dogma of arbitrary "free will"-as if every human being were always equally capable of choosing between any given course and its opposite-a dogma which is not only foolish, but mischievous, for it leads to the neglect of the way in which individual characters depend on their environment, and to the consequent neglect of the moral importance of political and social institutions. Ideas are themselves the outcome 
of institutions; and yet they constitute a factor that must be taken account of, if we are to form an adequate conception of social evolution.

What is effected by conscious effort is not necessarily in antagonism to what was going on in the unconscious stage. More often it is a continuation, an extension, an acceleration of a process already begun. In the higher organisms, even apart from consciousness, there is, at least according to Mr. Spencer's generalisation, less waste than in the lower. Thus the plants that are fertilised by insects produce fewer pollen grains than those which have no conspicuous flowers. Those which have fruits that are attractive to birds produce fewer seeds than cryptogamous plants, whose germs fill the air in countless myriads. The great mortality of savage life and the prevalence of infanticide are similar instances of waste which disappear more or less at higher stages in social evolution. It is very easy for the historian to show how much service has been rendered to mankind by fierce struggles, by war, civil dissension, economic competition. But does it therefore follow that equally good ends can never be attained at less 
cost? Strauss insists that it is as impossible to abolish war, as to abolish thunder-storms. To argue thus is to proceed like certain Indians who are said to cut down the fruit tree when they wish to pluck the fruit, or like Charles Lamb's Chinaman, who burnt down his house every time he wanted to enjoy the luxury of roast pig. Are we to have so much more faith in the blind passions of human nature than in what can be done by conscious effort? With these blind passions we must reckon, as with other forces in nature: but there is no reason why we should accord to them any special prestige, simply because they are natural. They are to be used or to be defeated according as our thinking decides.

War is natural only in the sense of being za the rrimitive form of the struggle between races riah. and nations, not in the sense of something which thesuth, ought to be. It has indeed contributed greatly to nation-making and to the development of the primitive virtues of courage and fidelity: Those tribes that were the bravest and the most coherent have been the most successful in the struggle for existence, and so these virtues have come to receive special respect. But let 
us notice with what limitations-courage was limited to the courage shown in the battle-field, fidelity was limited to fidelity towards one's own tribe. When reflection begins, and when imagination is developed, the sphere of courage and fidelity comes to be extended, at least in the minds of some of the more reflective and sympathetic individuals. It is precisely in this way that moral ideas, which are the product of social evolution, come to be capable of advance and progress. Customs - and customs are laws in their primitive form-are habits regarded as right, because, having been adopted, they have proved conducive to the welfare and success of the tribe or nation; but customs tend to survive long after the circumstances which called them into being have changed. If they become very hurtful, the people maintaining them will in the long run suffer in the struggle with nature or with other nations which have better customs, i.c. customs more favourable to success; but it is a gain to a people if its more far-sighted members discern the hurtfulness of a custom in time, and persuade or force their fellows to discard it before it is too late. This is in all ages the function of the 
political, religious, or social reformer-to save his people from destruction or decay by inducing them to change a custom which, however beneficial once, and in some respects, has now become mischievous. Such attempts imply no contradiction to the principle of modification by natural selection, but are themselves an illustration of it. Suppose an animal, whose ancestors lived on the land, takes to the water (or vice a'crsî) because circumstances have changed, or in order to escape from excessive competition ; it may succeed better. IVhen Themistocles made the Athenians into a naval power, this change was a quite analogous phenomenon. The difference is, that what Darwin called (confessedly as a mode of expressing ignorance) the "spontaneous" variation in the habits of the animal is supplanted by the deliberate adoption of a new habit among human beings.

Now among all the more advanced societies we find this conscious, deliberate adaptation supplanting the unconscious and spontaneous, though in the beginnings of the most successful institutions there is senerally a very large element of unconsciousness in the procedure. Thus the great discovery of representative 
government, which constitutes the chief difference between ancient and modern politics, which has made it possible for democracy to exist without slavery, and which has made it possible for large states to possess free institutions, came about mainly because Englishmen felt it inconvenient to attend personally when the King wished to obtain money : an irksome duty was readily transferred to others. ${ }^{1}$ But representative government, as maintained by civil war in the seventeenth century, and representative government as imitated in all the most advanced nations of the world, is something consciously and deliberately chosen. It is a further and more complex application of the convenient principle of "counting heads to save the trouble of breaking them." Federation, in its modern sense, ${ }^{2}$ is a still further and still more complex application of the same principle, though Strauss, with the prejudices of a German monarchist, thinks a federal state

${ }^{1}$ See Hearn, Government of England, and Edit. pp. $466 \mathrm{ff}$.

2 I add this qualification, because the Federations of ancient history appear not to have recognised, except in rudimentary form, the principle of representation, and thus belonged to a lower, not a higher, type of society than the city-state. 
inferior to a nation. We may feel dissatisfied enough with what representative institutions still are, even at their best and when honestly worked; but we should be indulging in a foolish paradox if we did not see that any such institutions are better than their absence, because of the possibilities they contain. Yet could any political thinker of the ancient world have believed such institutions possible? IVould he have believed it possible for free citizens to delegate their functions, even for a time, without surrendering their democratic freedom ? ' One can see in Strauss's book how little understanding the cultured German may still have of this great condition of political advance. ${ }^{2}$

Does not the introduction of representative government, which has solved and will solve

1 In enumerating the different kinds of oligarchy, Aristotle gives what is practically a definition of representative government (Pol. iv. I $\$$ S, I $29 S$ a 40); but this is merely put forward as a logical possibility. At least he gives no example, and this slight naming is the clearest proof of the absence of the idea from the mind of the greatest political thinker of antiquity.

2 The Old Faith and the Neri', sec. S I (German ed. IS75) $=$ sec. 77 Eng. Tr. 
many problems, however many it leaves unsolved, hold out the promise that similar good may be done by the substitution of some more intelligent methods for military and industrial competition? International arbitration and economic co-operation are as yet small beginnings, but not smaller than the first germs of representative government. So far as we have yet got, neither arbitration nor co-operation have done for society what their advocates hoped, but they may be the first "variations," which, if they prove their fitness, will bring into being a new species of civilised society.

Mr. Herbert Spencer considers that there are only two main types of society, the militant and the industrial: and in industrialism he comprehends an absolute system of laisses fairc, the extreme of individualism. It is strange that he should not see that the economic struggle is only a phase of the oldest form of struggle for existence-the struggle between individuals for subsistence, and that it therefore belongs to a lower type than the struggles between organised communities, where a strict organisation mitigates the intennal strife. It is 
difficult to see whence Mr. Spencer and his followers derive their ardent faith in a beneficent result from this struggle, unless it be, as already suggested, from an inconsistent survival of the old theological optimism or the metaphysical idea of Nature.

\$6. IDEAS AND INSTITUTIONS.THE "SOCIAL FACTOR."

But, it might be objected, the economic struggle is not unmitigated, for industrial competition is carried on amongst enlightened and educated people, who will consider one another and develop their altruistic tendencies, though not in excess. Yet so fearful is Mr. Spencer of the interference of the State with his social aggregate of warring atoms, that he will not hear of any education except what each family provides for its own members-a return to the patriarchal or "Cyclopic" type of society-or what can be provided by free competition between private teachers, who will run the educational business on strict commercial principles. Thus I am afraid the educational influences to which he looks will not operate rapidly. But why, it will be said, not trust to 
the spread of kindlier feelings among individuals to mitigate the harshness of inevitable natural laws? Why bring in the ponderous machinery of legislation? Why crystallise customs into codes, voluntary associations into definite political institutions?

I have already referred to the mischief and danger that may arise from customs which have outlived their use; but fixed customs, as Bagehot has so admirably pointed out, ${ }^{1}$ are essential in keeping society together, and, as all scientific students of ethics have come to see, morality is dependent upon institutions. IVe may have to fight against custom to get a hearing for new ideas; but we must make use of custom to get them realised. Ideas can only be productive of their full benefit, if they are fixed in institutions. Wecannot build up anything on a mere shifting basis of opinion. This principle is cqually applicable to the removal of old wrongs and to the introduction of new rights. Many kindly and enlightened persons here and there felt the evil of slavery, but their views were mere isolated private opinions till slavery was abolished by legal enactment in one country 1 P'h'sics and Politics, p. $25 \mathrm{ff}$. 
after another throughout the civilised world. Highly respectable and pious people in the last century had no objection even to the slavetrade. Now that slavery has been officially buried, it has not many friends left to shed tears over its grave. Certain eccentric individuals were disposed to favour religious toleration in the sixteenth and seventeenth centuries. But even those who, being inclined to heresy themselves, like John Milton and John Locke, extended the bounds of liberty pretty far, had very listinct limits beyond which they would not go. There is always the risk of an outburst of the persecuting spirit, even in communities that are not as a rule fiercely fanatical. Hence a great step is gained when in any country it is expressly and officially declared that distinctions of creed shall make no difference in the rights of citizens. It is often argued that the possession of the suffrage is of very infinitesimal value to the poor man and will do very little good to the poor woman when she gets it. What is a vote to those who are in want of bread? A vote is not merely an occasional and indirect means of exerting a small fraction of political influence, but, what is 
much more important, it is a stamp of full citizenship, of dignity and of responsibility. It is a distinct mark that the possessors of it can no longer be systematically ignored by governments and can no longer shirk the duty of thinking about public and common interests. The slaves of a kindly master, the subjects of a kindly tyrant or ruling caste may be very comfortable animals : but the master or tyrant may become unkindly or impotent, and the poor wretches who have been dependent on him suffer without being able to help themselves. It is always much easier to ignore an unuttered or feebly uttered claim than to revoke a right once granted. The same remark applies to the acquisition of representative institutions by a country or a locality : it marks a step gained which is not likely to be lost. Few persons, at least in this country, care so very much for the abstract advantage of a republic over a monarchy. A nominal republic may be less democratic than a nominal monarchy: and to change a state into a republic might in some cases be grasping the shadow and letting the substance go. But a republic has at least this advantage, that it does not call the 
sovereign power by the name of a person or dynasty, but proclaims it before all the world "the commonwealth." "Noblesse oblige:" and a republic sets up a higher standard of political morality and thus deserves to be more harshly judged, if it falls short even of a monarchy and imitates in any way the follies and vices that are hardly avoidable where there is a royal court.

Another reason why icleas should be embodied in institutions, is that institutions exert so great an influence upon human characteran influence sometimes ignored on professedly scientific grounds. Perhaps the most popularly accepted part of the evolution theory is the doctrine of heredity; but it may be questioned how far the popular view, nay, even the vicw of many who have been trained in science, is not in reality the survival of a very ancient superstition, ${ }^{1}$ the belief in an inherited family destiny, a belief which was the natural product of a time when the family or tribe was the social and

1 In a notice of this essay in Mind, vol. xir. p. 29r, it is actually alleged that I say that "the doctrine of heredity may be nothing more than the survival of a very ancient superstition!" I say nothing of the kind. I suggest that the pepular ilezo of heredity may be a mixture of science and superstition. 
moral unit. Plato, in the Lazus, ${ }^{1}$ professes to regard robbers of temples as persons suffering from an incurable malady, "a madness begotten in a man from ancient and unexpiated crimes of his race, destroying him when his time is come." Aristotle uses the idea to make a quiet professorial joke, when he is speaking about certain abnormal moral tendencies: he tells of the man who excused himself for beating his father by saying that it was an inherited practice in his family for the son to beat the father, and of another family in which the sons used to drag their father to the door but no further. ${ }^{2}$ There is indeed a singular fascination, horrible at times as it may be, in the idea that the experiences of ancestors survive as the feelings of the descendants; but a great part of the prevalent opinion about heredity seems to be only mythology or fiction masquerading as science. Of course one who is not a biologist has no right to a private opinion in a biological controversy. But one must feel a keen interest in the discussion at present going on, as to whether acquired characteristics are transmitted or not. The negative opinion
1 ix. $S_{54}$.
2 Eth. Nic. vii. $6 \S 2$. 
appears to be on the increase, i.c. the Lamarckian doctrine is tending to disappear from the evolution theory and the Darwinian principle of natural selection acting upon "spontaneous" variations is coming to be accepted as the sole factor in organic evolution. " "Use and disuse" seem at first sight so much easier to understand than "natural selection," that it will probably be some time before they lose their hold on the imagination. The temptation undoubtedly is to discuss the question at once in its application to human beings, but it can be more safely discussed with regard to the lower animals, both because the opportunities of cxperiment are better and because there is less risk of bias in forming inferences. In the case of human beings it is so very difficult to distinguish what is due to inheritance in the restricted sense of race-influence from what is due to imitation, early training, etc., which constitute inheritance certainly-but in a wider and a sociological, not a merely biological, sense. When people point to the remarkable way in which children resemble their parents, they are apt to forget that children as a rule are not merely the children

${ }^{1}$ See below, pp. 87,88 . 
of their parents, but spend all their earliest years with their parents. Even where a parent is clead, the child is told of his or her habits and ways of thought, and unconscious imitation of a father or mother, whose memory is regarded as something sacred, may account for a great deal. Mr. Galton, in his work on Hercditary Genius, admits that his investigations altogether suffer from the defect that there is so great a "lack of reliable information" about the peculiarities of females (p. $\sigma_{3}$ ). We shall have to wait till public careers are more abundantly open to women before much can be learnt from family pedigrees. It is certainly striking that, in the two sets of cases where Mr. Galton considers the maternal influence to be strong, viz., in the case of scientific men and in the case of pious divines (pp. I 6,276 ), his own explanation turns upon influence in early years and not upon mere birth. The clever mother encourages and does not discourage the inquiring child; the pious mother, if she manages to influence her son at all, directs all his thoughts and emotions into one channel. It seems very doubtful whether, except in fairy tales or romances, the child 
brought up away from its parents and in complete ignorance of them (for this also is essential to a fair experiment) would present any of their moral characteristics in a definite form. May we say that a certain amount of psychical energy is inherited, but the direction it takes is mostlydetermined by circumstances? - though we must admit that it may be of a kind which more readily takes to certain occupations than to others. Individuals start with inherited tendencies or capacities (

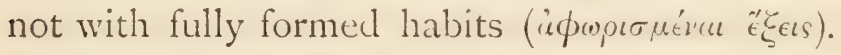
An energetic or an apathetic temperament, a cool or a nervous temperament is transmitted; but it scems very doubtful how far mere inheritance gaes beyond that, apart from the external influences in early life, which generally act along with it. As we sce so often, the son of people who have pushed themselves up in the world and made their fortune, may inherit the energy of his ancestors but not their business habits, and so he may only go to the devil more vehemently than others who come of a race longer accustomed to prosperity and who get an early training in the more elegant squandering of wealth. 
On this subject of heredity, though Darwin was too modest to urge his own discovery of natural selection to its full length, he is much more cautious in his statements than many who are fond of using his name. In his Autobiography, it is true, he says:- "I am inclined to agree with Francis Galton in believing that education and environment produce only a small effect on the mind of any one, and that most of our qualities are innate." 1 But in the Descent of $\mathrm{Man}^{2}$ his position is much more guarded, and he seems generally to allow early influence to account for more than inheritance, in respect of virtuous habits, etc. With regard to himself he says that he owed his "humanity" to the instruction and example of his sisters. ${ }^{3}$ His statement that "handwriting is certainly inherited" seems a very cloubtful one.*. In his

1 Iife and Letiers, I. 22.

2 e.g. Pp. 122-r25. On p. I23 he says:- "There is not the least inherent improbability, it seems to me, in virtuous tendencies being more or less strongly inherited." This is a very negative and cautious position.

"Life and Lctters, I. 29. "I doubt indeed whether humanity is a natural or innate quality."

+ Disicnt of Man, p. S8. He refers to Variation of Animals and Plants undir Domestiation, vol. II. p. 6. [See I. p. 449 in edition 2.] 
Life of Erasmus Darwin ${ }^{1}$ he say's that his uncle Charles Darwin "inherited stammering " from his father, Erasmus. "With the hope of curing him his father sent him to France, when about eight years old, with a private tutor, thinking that if he was not allowed to speak English for a time, the habit of stammering might be lost ; and it is a curious fact, that in after years, when speaking French he never stammered." Is not this "curious fact" an instantia crucis which proves that his stammering was not inherited? If it had been, he must have stammered in every language.

The lower down we go in the scale of animal intelligence the more seems due to inherited instincts: the higher we go the more is due to imitation and to the training rendered possible by the greater size and complexity of the brain and necessary by the prolongation of infancy. In the lower animals any habit which is useful to the preservation of the species can only be transmitted as an instinct. In the higher animals much can be done by imitation and instruction. Among human beings, language and social institutions make it possible to

${ }^{1}$ p. So, quoted in Life and Letters, I. 7. 
transmit experience quite independently of the continuity of race, so that even if a family or a race dies out altogether, its intellectual and moral acquirements and culture are not necessarily lost to the world. An individual or a nation may de more for mankind by handing on ideas and a great example than by teaving numerous offspring. Darwin himself fully admits this :-

" $A$ man who was not impelled by any deep instinctive feeling to sacrifice his life for the good of others, yet was roused to such action by a sense of glory, would by his example cxcite the same wish for glory in other men, and would strengthen by exercise the noble feeling of admiration. He might twus do for more good to his tribe than by begetting offspring with a tendency to inherit his own high character." (Descent of MIan, p. I32.)

"Great lawgivers, the founders of beneficent religions, great philosophers and discoverers in science, aid the progress of mankind in a far higher degree by their works than by leaving a numerous progeny." (ib. p. I36.)

What Darwin says here of the greatest of men is also in a less degree true of men generally. Most certainly we inherit from those who have gone before us: but the "inheritance" in any advanced civilisation is far more in the intcllectual and moral environment-in the 
spiritual air we breathe, than in the blood that runs in our veins. ${ }^{1}$

Mr. Galton's investigations on heredity do not appear to commit him to the Lamarckian or Spencerian view that acquired intellectual or moral characteristics are inherited; and, as we have already seen, he in some cases fully recognises how much the environment of the individual in early years affects his course in life. But it cannot be denied that Mr. Galton seems to lend countenance to a sort of fatalism about the influence of race, and to a too contented acquiescence in existing social arrangements. I say advisedly "seems," because I do not think Mr. Galton's book is quite as comforting to the opponents of change, if they come to read it carefully, instead of merely claiming its authority on their side. Let us consider a few passages in detail. "It is in the most unqualified manner that I object to pretensions of natural equality. . . . I acknowledge freely the great power of education and social influences in developing the active powers of

${ }^{1}$ Cp. Lewes, The Study of Psychology, pp. 78-80, where it is urged that the operation of "the social factor" constitutes the difference between man and the lower animals.

D. P.

E 
the mind, just as I acknowledge the effect of use in developing the muscles of a blacksmith's arm, and no further." There is a definite limit to the muscular [and intellectual] power of every man, which he cannot by any education or exertion over-pass. ${ }^{1}$ If this is the dictun of science, it might seem for a moment to deal a fatal blow to the aspirations of democracy. But does it? Equality, we need to be reminded, is not a fact, but an ideal-something at which we have to aim. And one of the main things we may hope for in a better organised society is that the world will not lose or waste so much of the intellectual genius in its midst. We need all the eminence, intellectual, moral, artistic, that we can get-not that the eminent individual may amass a fortune or receive the fatal gift of the peerage (as for those that care for such things-verily they have their reward), but that he may exercise his gifts, as all the world's greatest men would wish to exercise them, for the benefit of his fellow-men. Mr. Galton seems indeed to suggest that eminent men generally do come to the front as it is; but his statement is a little 
rash, and he hardly counts the cost of the struggle.

"If the 'eminent' men of any period had been changelings when babies, a very fair proportion [what does he consider such?] of those who survived and retained their health up to fifty years of age, would, notwithstanding their altered circumstances, have equally risen to eminence. Thus-to take a strong case-it is incredible that any combination of circumstances could have repressed Lord Brougham to the level of undistinguished mediocrity." (p. $3^{8 .)}$

Mr. Galton's example is well chosen for his purpose. Lord Brougham was just the kind of man who would anywhere have pushed himself into notoriety of some kind. But those social hindrances which "form a system of natural selection" may allow a great many Lord Broughams to come to the front in different disguises and yet may repress some who might do the world more service than an indefinite array of Lord Broughams. Supposing Mr. Darwin had had to pass his life as an overworked and over-worried country surgeon or had been a factory hand in a huge manufacturing town, he might conceivably have been a noted man in a small naturalists' club and been laughed at by his neighbours for collecting 
beetles; but would he have discovered the origin of species and proved his discovery by long years of continuous research? It is perfectly true that "social hindrances cannot impede men of high ability from eminence," and that "social advantages are incompetent to give that status to a man of moderate ability." But "social hindrances" may exhaust all the energy of the ablest in the bare struggle for existence, and may direct the energy of those who do succeed into wrong and mischievous channels. We cannot invent a social machine for manufacturing genius, but we might do something to eliminate the waste and misapplication of genius that goes on at present. Commercial competition and the fight for social preeminence offer terrible temptations to the scientific worker, the writer of books, the artist.

Mr. Galton himself proposes what would amount to a very considerable reorganisation of society, and suggests some principles which consistency and practical necessities might oblige us to carry a little further :-

"The best form of civilisation in respect to the improvement of the race, would be one in which society was not 
costly; where incomes were chiefly derived from professional sources, and not much through inheritance; where every lad had a chance of showing his abilities, and, if highly gifted, was enabled to achieve a first-class education and entrance into professional life, by the liberal help of the exhibitions and scholarships which he had gained in his early youth; where marriage was held in as high honour as in ancient Jewish times; where the pride of race was encouraged (of course I do not refer to the nonsensical sentiment of the present day, that goes under that name); where the weak could find a welcome and a refuge in celibate monasteries or sisterhoods; and lastly, where the better sort of emigrants and refugees from other lands were invited and welcomed, and their descendants naturalized." (p. 362.)

On almost the last page of Mr. Galton's book we have these words:- "The human race can gradually modify its own nature." (p. 375.) Take along with this a conclusion of Darwin's:- "It may be doubted whether any character can be named that is distinctive of a race and is constant," ${ }^{1}$ and I do not think there remains much excuse for the conclusions of fatalism and laisses faire that are often drawn from the doctrine of heredity. Especially, if we cannot trust to acquired habits being transmitted merely by descent, have we additional 
reason for surrounding each successive generation of individuals, from their youth upwards, with institutions and laws and customs that will promote good and hinder bad tendencies. The moral significance of the organisation of society can hardly be over-estimated. It is little use preaching kindliness and consideration for others and hoping that sympathetic feelings will gradually become innate, if the society into which individuals are born be openly and confessedly a ceaseless struggle and competition. For eighteen centuries a gospel of peace and brotherhood has been preached and talked; but the child plays with a toy gun and the youth sees the successful millionaire held up as his model for imitation-the man who boasts that he is "self-made," and who, as the American remarked, has by that boast "taken a great responsibility off the Almighty." Not only education, but the very amusements and healthy exercises of school life are all infected and corrupted by this diseased spirit of competition. No wonder that those are scoffed at or denounced who venture to think that a society of rational beings might proceed more rationally. From the fact that human societics, 
like natural organisms, grow and are not made, we have certainly to learn that every evil cannot be remedied in a day. But from the other, at least equally important fact, that human societies do not merely grow but are consciously altered by human effort, we have also to learn that every evil is not to be accepted as inevitable. The spread of ideas regarding a better organisation of society is itself a factor in the attainment of that better organisation-not, of course, that we can make out a complete plan, like an architect, and then get it put into practice. Time and experience alone can suggest the details. But the teaching of evolutionary science, rightly understood, gives us no excuse for putting aside all schemes of social reorganisation as merely foolish and dreamy idealism. A fair study of social evolution will at least indicate the direction in which we have to move.

§7. THE LAW OF SOCIAL PROGRESS.

Hitherto in my argument I have accepted the formulx of "struggle for existence" and "natural selection" as quite sufficient to ex- 
press the evolution of human society. They are quite accurate, if applied with a full recognition of the new elements which enter into the struggle over and above those operating in the biological sphere. But perhaps these formulx, though accurate, hardly express the whole truth. Mr. Spencer's Pecognition of only two great types of society-the militant and the industrial-and his theory that social evolution ends in complete individualism are scarcely consistent with his own insistence on the organic or super-organic nature of society. Sir Henry Maine has only one great formula-that society advances from status to contract-and sticks there or else goes backwards. Is there not a higher type of society beyond and above each of these onesided extremes-cohesion without individual liberty and individual liberty of the negative sort without social cohesion?

In human society thought or reflection, as we have seen, enters in as a factor, lifting it above the merely natural organism, and so perhaps we may look at the nature of thought in order to find out the way in which society progresses. On every subject we think about we begin with some rough opinion, either received from others 
or the result of hasty observation. If we go on to think about this opinion, we have to question it, to examine it, and unless we come to a standstill at the stage of doubt or criticism, we go on to form some more adequate opinion, which may indeed be only the old opinion in a better form or may be something very different. But this new opinion may in its turn be questioned in order to be corrected, and so on, for the truth always proves itself more complex than at first appeared : and, unless we lazily acquiesce in dogmatic solutions, we cannot cease from the labour of thinking. It might indeed be more prudent to avoid mentioning Hegel's name; but this very commonplace process is his "dialectic method" in its simplest and most familiar form. This "advance by negation" is the way we have to think about everything. And if we apply this dialectic method to society, what does it suggest? That we cannot rest in the critical or negative stage of modern individualism. But does that imply a ireturn to the mediæval type of society? to " the good old days" of aristocratic and ecclesiastical domination? By no means. It implies an advance to a stage in which all that is most 
precious in individualism must be retained along with the stability of social conditions which individualism has destroyed. And this new stage can be best described by the word "Socialism."

\$. APPLICATIONS.

By way of practical application, let us use the light gained in our study of the nature of social evolution generally to consider in detail three great parts of the social problem: (I). State interference with the condition of labour, (2) the position of women, (3) the population question, which is obviously connected with both the preceding.

(I) Strauss, to whom I have referred before as professedly applying the new faith of Evolution to the practical guidance of life, objects. cven to trade-unions agitating for a reduction of the hours of labour.' He is so hot upon the point that his patriotism, which elsewhere seems to constitute the principal part of his morality, deserts him here, and he suggests that

1 The Old Faith and the Net', sec. $8_{3}$ in German edit. $1875=$ sec. 79 (ii. p. 98 ) in Eng. Transl. 
the employers of labour should "if necessary send to foreign countries for workmen and then let the refractory see who will be able to hold out longest." This is the struggle it outrance, though he makes no express reference to the evolutionary formula here. Few thoughtful Englishmen would now venture to go so far as that and deliberately to propose, as Strauss does, the complete suppression of the liberty of association among the workmen, however much they may envy autocratic methods and imitate them, when they get the chance, on a small scale and in a feeble way. But there are very many, even of our most Radical politicians, who, while allowing or encouraging trades-unions to struggle for higher wages and a reduction of the hours of labour, object to the State meddling at all in the matter, except in the case of women and children, or as J. S. Mill would have put it, except in the case of children only. Adults are to be left to shift for themselves. Well, we know what that means. It is needless to use any vivid or picturesque language. Those who have eyes to see and ears to hear can see and hear for themselves. This system of unchecked competition-one cannot repeat it too 
often-means a prodigal and frightful waste. Some have to work too hard and too long: others cannot get any work to do at all or get it irregularly and uncertainly: others, who might work, do not and will not-the idlers at both ends of the social scale, the moral refuse produced by our economic system. This system is exactly what we find in nature generally; but one would think that human beings might use their reason to discover some less wasteful scheme. Water will find its own level; but how much mischief may it cause in so, doing? - mischief which can be avoided. We have beautiful flowers or miserable weeds in our gardens according as a skilful gardener "interferes" or not; and when he thins out an overcrowded bed, he need not throw away the plants: there are many who would be glad to have them. It is all one great problem of distribution. Here is so much work needing to be done and so many persons to do it. The organisation of labour is not an easy task; but is it hopeless? At least we might diminish the disorganisation, which is the system of mere nature, as that appears to rational beings. Cannot human societies imitate the higher 
forms of nature, not the lower, so as to contrive some scheme for the diminution of waste?

Strauss is afraid, because of the interests of civilisation. But the civilisation he thinks of is that of the antique type of society, a civilisation limited to the few-a cultured minority, consoling themselves for the loss of old religious beliefs by reading poetry and hearing concerts and operas, amid a subject-multitude treated with some consideration, like dependent and useful lower animals, but left to poverty and superstition. What can be worse for civilisation than that the more energetic and successful workers, managing to get constant employment, have, as at present, no sufficient leisure for the cultivation of their faculties? And when in the case of the greatest number all available energy is used up in the struggle to feed the body, what wonder that the soul is neglected- "where a soul can be discerned"? Leisure is necessary for culture : and a moderate amount of work is good for physical, mental and moral healthexcess is bad for all three. Cannot leisure and work be better distributed, according to a rational instead of a hap-hazard system? In the attempt to substitute rational for non- 
rational methods there is no denial of the scientific truth of evolution, and there is an application of the principle on which Strauss himself insists so strongly, that "man must not merely be an animal repeated, but must be something more, something better."

(2) The claim of women to an equal share with men in the advantages and responsibilities of education and citizenship is very frequently met by the objection that to grant this claim is to fly in the face of nature. And the objection, when it comes from the evolutionist, has a certain plausibility. He points out, perhaps, how advance in organic life goes along with increasing differentiation of sex-a rash assertion $\mathrm{n}$ biology, but I have heard it made by a biologist. And so, it is asked, are not the advocates of women's rights trying to reverse all that, and to produce a morally asexual being? Again, if we limit ourselves to human society, it is urged that "the difference between the sexes, as regards the cranial cavity, increases with the development of the race, so that the male European excels much more the female, than the negro the negress" (quoted from Vogt by Darwin, Desccnt of Man, p. $566 n$,; but it is 
admitted that more observations are yet requisite before the fact can be positively asserted). It is argued from this fact, if such it bc, that the progress of society has brought with it a still greater differentiation of sex, and, this having proved beneficial for the human race, it is folly to seek to reverse it. Let us take the last argument first. Because a certain method has led us up to a certain point, it does not follow that the same method continued will carry us on further. Races that have reached a certain stage may be hindered by extreme conservatism from making any further progress-like the Chinese. Again, at what degree of differentiation between the habits and lives of the sexes are we to draw the line? Englishmen, Frenchmen, Turks would draw it very differently. And the Turk ought to please the biological Conservative best, because he has pushed the differentiation of the sexes to a logical issue. The persons who use this kind of argument fancy that they are influenced by scientific considerations, but they are really influenced by what they happen to have grown accustomed to. Thirdly, if there is this greater difference between the cranial cavities of savage and 
civilised men than between those of savage and civilised women, to what must it be due?

(a) Those who believe that acquired characteristics (i.e. characteristics produced by agencies external to the organism) are transmitted, must explain this difference by the difference in institutions, laws and customs. Well, then-what these have done before in one direction they may do again in another. And the same education and the same responsibilities will, in course of time, put the average woman on the same level with the average man. (b) If use and disuse are not allowed as explanations, then this alleged brain inferiority of women must be due either to natural or to sexual selection. (a) If to natural selection, this would mean that in the struggle for existence those races or tribes have succeeded best in which the males have on the average had better brains than the females. And this may have been so in times when constant fighting was necessary for existence, though in such a case it would be the greater superiority of the male and not the greater relative inferiority of the female that had been the real cause of success. But this affords no 
argument that, when many other conditions of success than fighting power become necessary, the process of natural selection will continue to act in the same way. A people, all whose members become superior in mental qualities, will have the advantage over those peoples in which the development is partial and onesided; for, certainly, it could not be argued that the (alleged) relatively greater inferiority of the civilised female brain had grone along with an increased capacity for the purely physical functions of maternity, as compared with what is found among savage races. $(\beta)$ If, on the other hand, the alleged difference is due to scuual selection, this must mean, not merely that men as a rule have preferred women with inferior brain power to their own (which is likely enough), but women whose female children were also on the average inferior in this respect to their male children. Supposing such a kind of selection to be possible (one can only admit it for the sake of argument), then, if men's ideas about women come to be altered, sexual selection will work in an opposite manner. IVith a new ideal of woman, the clever would be preferred to the stupid, and the

D. $P$. 
mother of clever daughters to the mother of stupid daughters. Thus, even if the assertion of Carl Vogt were true, it offers no conclusive argument against the political and social equalisation of the sexes; because this equalisation would on any recognised principles of evolution, bring about ultimately a natural equality. On the whole, however, one may fairly retain the suspicion that this alleged difference is not a fact, and that the greater average eminence (in the past) of men than of women in intellectual pursuits is entirely due (as on any theory it must be mostly due) to the effect of institutions and customs and ideas operating within the lifetime of the individual, and not to differences physically inherited. Little girls are certainly not on the average stupider than little boys: and, if on the average men show more intellectual ability than women, may not this be due to the way in which the two sexes are respectively treated in the interval?

But, even if there were an avorage mental superiority in men due to sex-differentiation becoming greater with the attainment of maturity (we have really no right to make definite assertions on the subject, because women have never 
yet had a fair chance of showing their capacities on a sufficiently large scale), Plato's argument would still hold that, though there may be a general superiority of men, yet there are many women superior to many men, and it is a pity that the State should lose the advantage of their services. ${ }^{1}$

With regard to the argument from nature generally, even if we agree to the generalisation that advance implies increasing differentiation of sex and not the very reverse, it must be insisted that difference is not the same thing as incquality (though the two are very apt to be confounded), and that the very difference between the sexes is a reason why the State should not disregard the opinions and the feelings of half, or in old countries more than half, the population.

But the main point is really this : that society has enabled man to rise above the mere animal and, as has been pointed out, to be influenced not merely by natural pressure but by ideas. The idea of equality has grown up-I shall not at present inquire how far it is due to the universal citizenship of the Roman Empire and to

${ }^{1}$ Republic, v. 455. 
the widening conceptions of Roman Law, how far to the Stoic philosophy with its brotherhood of mankind, and how far to Christianity as an inter-national or non-national religion, declaring the equality of all before God, though carrying with it the Judaic supremacy of the male sex. When this idea of equality was proclaimed in the American revolution, the negro slaves were conveniently overlooked; when it was proclaimed in the French revolution, the existence of a whole sex seemed to be forgotten by every one but Condorcet. And there are many oldfashioned Radicals still, who lack sufficient faith in their own creed to apply it in a thoroughgoing way. How often does one hear the argument, "Oh, but women are naturally Conservative, and if they had political power, we should be governed by the priests." It may rather be said that the instability of republican government in France has been very much due to its not having appealed to the sympathies of the mothers of the French people. If women are expressly and purposely kept in the patriarchal stage of social evolution, is it wonderful that their feelings and sympathies mostly correspond to an antique social type? It is 
hypocritical to deny the political capacity of women, simply because their political incapacity has through long centuries been diligently cultivated; but this is always the favourite sort of argument with the jealous champions of privilege :--first to prevent a race or class or sex from acquiring a capacity, and then to justify the refusal of rights on the grounds of this absence - to shut up a bird in a narrow cage and then pretend to argue with it that it is incapable of flying. What is the reason of the power which the Catholic Church possesses over the minds of women, except that the Church alone offers them any escape into a larger circle of interests than those of the patriarchal family? They do not rellect that the Church brands them with a stamp of inferiority, ${ }^{1}$ that did not

${ }^{1}$ Even the cult of the Madonna, which is a revival of the female element in deity, did not do away with the degradation of the woman. There is a story (given in Grimm's Household Tirles, Note to Tale I39) of St. Bernard, that he once went into a Cathedral to pay his devotions to the image of the Virgin. He fell twice on his knees before it, and full of fervour uttered the words, "Oh, gracious, mild, and highly favoured mother of God." Hereupon the image began to speak, and said, "Welcome, my Bernard!" But the saint, who was displeased by this, reprimanded the Queen of Heaven for speaking, in these words, "Silence! 
exist in the old Aryan religions, which had their gods and goddesses, priests and priestesses. They do feel that the rule of the priest may be something higher than the rule of the household despot. Religious teachers have understood that their success must depend on their winning the mothers of the race. When will political leaders come to recognise the same?

No woman is to speak in the congregation!" This is an admirable illustration of the ecclesiastical and sentimental theory of womanhood-a worship that professes to exalt woman-whether the Madonna or das Ewig-IVeiblicheabove man, combined with a refusal of rationality that sinks her beneath him. The same thing appears in quarters where we should less expect it. Thus we find the late Mr. Laurence Oliphant, who with many protests against the corruption of the Churches, builds up on a strangely unscientific foundation what professes to be a new "scientific" religion, and who proclaims a higher code of morals, based mainly on the elevation of women, yet denouncing, like a Catholic or a Comtist priest, the agitation for "women's rights" and "the higher education of women," and maintaining the very retrograde and (in these days) immoral doctrine that women have 110 responsibility, with regard to public affairs. (Scientific Religion, pp. 316, 324.) In fact, the "Divine Feminine" or "Woman" - with a very big capitalis one of the worse enemies that women have to contend with in their struggle towards recognition as complete and responsible human persons. 
Mr. Herbert Spencer ${ }^{1}$ is afraid that women, if admitted now to political life, might do mischief by introducing the ethics of the family into the State. "Under the ethics of the family the greatest benefits must be given where the merits are smallest, under the ethics of the State the benefits must be proportioned to the merits." Mr. Spencer seems to have more confidence than most of us would in applying the strict principle of geometrical proportion to distributive justice. Do people gret benefits in proportion to their merits in any society we have ever seen or are likely to see? And would those persons whosi morits are greatest care most for the greatest rwards? Is it right to separate the ethics of the family, in Mr. Spencer's favourite antithetic fashion, from the ethics of the State? If something is right in a family, it is difficult to see why it is thoreforc, without any further reason, wrong in the State. If the participation of women in politics means that, as a good family educates all its members, so must a good State, what better issue could there be? The family ideal of the State may be difficult of attainment, but, as an ideal, it is

${ }^{1}$ Sociology, 1p. 793, 794. 
better than the policeman theory: 1 It would mean the moralisation of politics. The cultiva-

I In the same notice in Mind to which I have referred, above (page $4 \mathrm{I}$, note) the writer says this passage is inconsistent with page 68 , where I speak of the patriarchal stage of social evolution as already transcended. Does he really suppose the ethics of the family, in Mr. Spencer's sense, to belong to the patriarchal stage of society? By the patriarchal stage I understand what Maine and all other writers on the subject mean by it-the stage which is prior to political society in the proper sense. On page $68 \mathrm{I}$ argue that to refuse to women the duties and responsibilities of full citizenship is injurious to the common weal, because half the adult population is thus kept (so far as institutions can keep them) in the mental and moral condition of "survivals" from a superseded stage of society. Here I am arguing that Mr. Spencer is mistaken in making an absolute antithesis between the ethics of the family and the ethics of the State. What is right in the smaller association cannot, I contend, be ultimately wrong in the larger, though it may be more difficult of attainment. I should indeed wish to amend MIr. Spencer's formula for the ethics of the family ("greatest benefits where the merits are smallest "), first of all by giving up the fallacious appearance of mathematical exactness and, secondly, by ceasing to talk about "merits." A baby may receive the greatest amount of care in a household, but not because its merits are smallest. I should prefer to say: "Every one to work according to capacity : every one to receive according to need, so far as compatible with the well-being of the family as a whole." (Of course "capacity" and "need" are not the same things as "wishes.") Is not this our ideal of family ethics? And, if it is a right ideal, 
tion of separate sorts of virtues and separate ideals of duty in men and women has led to the whole social fabric being weaker and unhealthier than it need be.

The history of the position of women is much more complex than is often represented. It is not true to say that the status of women has always improved in direct ratio to the greneral advance. The patriarchal stage represents on the whole a higher type of civilisation than the matriarchal. But, it is to be observed, those societies which have exaggerated the patriarchal type and built all their civilisation upon it, seem to be incapable of advancings further. This is conspicuously the case with Mohammedan peoples. Just as war has fulfilled important functions in the progress of the human race, so the terrible powers of the house-father in certain ancient systems of law have had their use : but it does not follow that what once aided the race in its struggle with

must it not come to be our ideal of social ethics generally, because it is the system which would involve the least waste of life and energy? Of course the compromise of equality is frequently needed to save disputes, and so avoid waste in another way. 
other races will continue to do so when the struggle becomes of a higher and more complex kind. ${ }^{1}$

The objection is sometimes made that, in countries where it is considered necessary to have compulsory military service for all males, it would be unjust and inexpedient that women should have a voice in political matters. This objection would be easily met by compelling all women physically fit for it to undergo training as nurses, and making them liable to be called upon to serve as such in time of war. $^{2}$ And this training would be more useful to them and.

1 "Such is the rature of men that, when they have reached their ends by a certain road, they cannot understand that, the times being different, success may be won by other methods and the old ways are no longer of use." These words represent the theme of the 9 th chap. of Machiavelli's Discourses on Livy, Bk. iii.

"A probably reverend reviewer in the Guardian has understood this passage, as if I imagined an army of "four-andtwenty fighting men and five-and-twenty" - nurses! In the very next sentence I suggest that nurses are useful elsewhere than in military hospitals. I quite admit, however, that until all service for the community, whether it be fighting the enemy in the field or fighting disease in the sick-room, come to be treated as "public service," we can have no genuine social equality. This is implied in the next paragraph. 
to the whole community in time of peace than his military training is to the peasant or artisan.

Of all the objections made to the equality of the sexes the only one that deserves very serious attention is that made by Sir James Fitzjames Stephen in his clever attack on J. S. Mill. He points out (in Libcrty, Equality, Fraternity, $\left.{ }^{1}\right)$ that women may suffer more than they have done, if plunged into a nominally equal but really unequal contest in the already overcrowded labour market. The conclusion usually drawn from this argument is a sentimental reaction in favour of the old family ideal (for instance in Mr. Besant's books). There is another alternative, and that is the socialistic. The elevation of the status of women and the regulation of the conditions of labour are ultimatcly inseparable questions. On the basis of individualism I cannot see how it is possible to answer the objections of Sir J. Fitzjames Stephen.

1 Pp. 253, 254. (Edit. 2.) Sir J. F. Stephen sees quite -clearly what is hid from the eyes of many Liberals, that the change from status to contract produces "not equality but inequality in its harshest and least sympathetic form " ( $p$. .249). 
(3) I began by referring to Malthus, and with Malthus I must end. Socialists have usually brushed aside the Malthusian precepts and somewhat too lightly neglected the Malthusian arguments. To some extent this has been due to a correct instinct. The "prudence" of the old school of political economy would mean that the most careful and intelligent part of the population should leave the continuance of the race mainly to the least careful and the least intelligent portion-thus bringing about a survival of the unfittest. And so the theory of natural selection, which was suggested to Darwin by Malthus's theory of population, has come to be used as a refutation of Malthus's practical suggestions. ${ }^{1}$ Socialist views on the question have not always had so scientific a basis, but have sometimes rested on nothing much better than the popular superstition that where God sends mouths he sends the food to feed them, though this may be disguised in a non-theological form, such as "the earth is capable of producing abundance of food for all its inhabitants." Now what does this mean? That the earth at present may be ${ }^{1}$ Cp. Galton's Hereditary Genius, p. 356. 
made to bear more than it now does, and that therefore it will maintain more than its present number of inhabitants, is true enough. But only a complete failure to grasp the meaning of the struggle for existence, and the relation between increase of means of subsistence and increase of population could lead any one to maintain that, absolutely; the earth can be made capable of supporting an indeñnitely increasing number of inhabitants. If the checks on population supplied by famine, war, pestilence and vice be removed in any large measure, the increase would in time outrun any possible increase in the means of subsistence, even with all that improved appliances and diminished waste could do. Here, as elsewhere, human beings must raise themselves above unthinking animals and not trust to a kind Providence in which they take no part. The course of events, if left to itself, will act in the way that we do, when we dispose of superfluous puppies and kittens, but not quite so rapidly and mercifully. We must become provident for ourselves. But what is to be said of the Darwinian objection, the protest "against the higher races being encouraged to withdraw 
from the struggle for existence" ? That would be a valid objection, if we suppose the present system of free competition in the labour market to continue for ever. If employers of labour remain a separate class (instead of becoming directors of labour, acting solely on behalf of the whole community), and are free to import the labour of cheaper and more prolific races, as we have seen even the patriotic Strauss suggesting, there would certainly be a continuous degeneration of the species. But, most assuredly, the day will come and very soon, when the workers of all the more civilised nations will join together not to undersell each other; and by that time employers will not be absolutely free to import Chinese or Malays, who would practically be slaves of a new type.

It might, however, be objected that if the more civilised nations keep their numbers fairly on a level with the means of subsistence at home, there will no longer be the stream of emigrants pouring forth from our shores to civilise the world and develop the resources of new countries: "the abler races" will be "withdrawing from the struggle for existence." There are some people who seem to think that 
an unlimited supply of what we call the AngloSaxon race is the best remedy for all the evils of the world. Well, without wishing to be needlessly unpatriotic, I do not think the unlimited Anglo-Saxon is an altogether unmitigated blessing. The filibuster, the mercantile adventurer and the missionary have not been so perfectly successful between them in dealing with the problem of the lower races; for the mere disappearance of lower races before the rum supplied by the trader and the clothes enjoined by the missionary (to the great profit of the Lancashire manufacturer) is not quite a satisfactory solution. What has been already said about the transmission of a type of culture, irrespective of the continuity of the race that first developed it, seems to help one here. IVe need have less doubt of the excellence of our language and of our literature and of some of our institutions than of the supreme excellence of our race: and there is nothing to prevent distant tribes and nations regarding Europe, and Britain not least, as the school or university to which they shall send their most promising youth in order to adopt just as much of our civilisation as suits them, so that they may 
work out their problems in their own manner. That would surely be a healthier way in which the higher might affect the lower races in the future, educating them instead of enslaving, demoralising or destroying them.

As to the adjustment of population to subsistence, Mr. H. Spencer has sufficient faith in the beneficence of nature to believe this will come about of itself through a biological law-that multiplication and individuation vary inversely, so that, as the physical and intellectual culture of the individual is more and more attended to, the increase of the species will gradually diminish. This "law" is, however, as yet only a mere speculation of Mr. Spencer's. There does seem to be in the world a certain amount of what we may call natural adaptation, which leads the more cultured and the more settled nations to be less prolific than those of the same race or stock who are living in new countries with plenty of elbow-room. The English race in Western America or in Aústralia does seem to be more fruitful than in old England or in New England. But the whole theory is a very doubtful one. And a rational adaptation of means to ends seems requisite to obtair: 
the desired result. This is pre-eminently a question which can only receive proper consideration and solution when women are admitted to full social and political responsibility. It is the woman who bears the suffering of maternity and has the care of the very young, and so the woman is more immediately interested than the man. So long as women were brought up to believe that their sole or main function in life was to bear children, and were made to feel that there was something not only of disadvantage but of disgrace in being unmarried or childless, what wonder that population has been increased indefinitely and recklessly? Every inducement was in that direction, the ideas of a military society, the influence of the clergy (and, at least in Protestant countries, their example also), the employment of child-labour before the factory acts, the system of our old poor law - everything encouraged the natural tendency of the race to increase. With a change in the prevalent sentiment, a change in fact will certainly follow. When women have other interests in the world than those of maternity, things will not go on so blindly as before. And the race need not necessarily suffer thereby, but

D.P. 
the very reverse. Fewer children will be born, but fewer will die, fewer will be sickly. Those who are born will be better and more intelligently cared for. Two healthy, well reared children will be more useful to the community than a dozen neglected waifs and strays. Here, again, we shall only be imitating by rational procedure the upward tendency of nature, which consists in the economy of production. Rational selection will take the place of the cruel process of natural selection.

If we are still reminded that only through struggle can mankind attain any good thing, let us remember that there is a struggle from which we can never altogether escape-the struggle against nature, including the blind forces of human passion. There will always be enough to do in this ceaseless struggle to call forth all the energies of which human nature at its very best is capable. At present, how much of these energies, intellectual and moral as well as physical, is wasted in mutual destruction! May we not hope that by degrees this mutual conflict will be turned into mutual help? And, if it is pointed out that even at present mutual help does come about, even 
through mutual conflict, indirectly and with much loss on the way, may we not hope to make that mutual help conscious, rational, systematic, and so to eliminate more and more the suffering going on around us? 

II.

NATURAL SELECTION AND THE SPIRITUAL WORLD. 

S. DARIVINSII COMPLETE AND INCOMPLETE.

" DARINISII," the title of the delightful book which Mr. Alfred Russel Wallace published in 1889 , is a splendid proof of an absence of jealousy not too common, even in scientific minds; but it is also an express declaration of what Mr. IVallace understands by the evolution theory. Mr. Wallace is more "Darwinian" than Darwin himself. Darwin put forward "natural selection" as only one among the factors of organic evolution: he did not attempt to set aside the old Lamarckian theory of the hereditary transmission of the effects of use and disuse, although natural selection was his own discovery-a discovery made independently by himself and by $\mathrm{Mr}$. Wallace. It has been lately said by Professor Patrick Geddes, ${ }^{1}$ that there is at the present time "a growing tendency to limit the impor-

${ }^{1}$ Evolution of Sex, p. 304. 
tance of natural selection." This statement will doubtless cause great satisfaction to the Duke of Argyll; but I do not know what proof can be given for its truth, except the opinion of Professor Geddes himself, of Mr. Herbert Spencer, and of a few American biologists; according to biologists such as Mr. Russel Wallace, Professor Weismann, and Mr. E. B. Poulton, the tendency is now all the other way. And this is admitted by Mr. Grant Allen (in spite of his admiration for Spencerian psychology) in a very remarkable review of Professor Weismann's papers On Hcredity, in the Acadcmy of February I, I89o. In any case, there is this difference between natural selection and the other alleged factors of organic evolution, that they are speculations, more or less metaphysical in character, whereas natural selection is a fact; it is a cause actually at work in nature, and the only question is, whether it is able or not to explain all the phenomena. On the other hand, Mr. Spencer's "differentiation and integration," Professor Geddes's see-saw of "anabolism and katabolism," Mr. Cope's " bathmism" or growth-force, which acts by means of retardation and acceler- 
ation (and which Mr. Darwin found himself quite unable to understand), remind us of the theories about Nature that were thrown out by the older Greek philosophers-above all, of the "love and strife" in the poetic system of Empedocles. Such general formulæ may help to make the universe more intelligible to us, and may possibly suggest profitable lines of investigation to the inquirer, who is otherwise too bewildered by details; but they stand on a perfectly different level from the everywhere present fact of the struggle for existence, in which those organisms that happen to possess useful variations have a better chance of succeeding and transmitting these useful qualities to offspring than those less favourably equipped. The hereditary transmission of the effects of use and disuse has been very readily accepted by the popular imagination, and has indeed bulked most largely in current versions of evolution, because it has fitted in perfectly well with traditional beliefs about hereditary curses, and with the theological doctrine of "original sin." "The fathers have eaten sour grapes, and the children's teeth are set on edge." People who make stale jokes about the ances- 
tral ape wearing off his tail by sedentary habits imagine that they are putting Darwin's theory in a comic light, but have probably never taken the trouble to understand natural selection. ${ }^{1}$ The facts which, it has been supposed, can only be explained by the transmission of the effects. of use and disuse, turn out, however, either not to be facts at all-a misfortune that often happens to "facts" - or to admit of a perfectly satisfactory explanation by the cessation of natural selection. Thus the various contrivances of civilisation, including spectacles, make defective vision less injurious to human beings

1 Here are two stanzas of a song on "The Origin of Species" by a late learned and witty Scotch judge. They are entirely "Lamarckian," though probably intended, and. certainly generally believed, to represent Darwin's theory.

"A deer with a neck that was longer by half Than the rest of its family's (try not to laugh), By stretching and stretching became a giraffe, Which nobody can deny."

* * * * * * *

"The four-footed beast that we now call a whale Held his hind-legs so close that they grew to a tail, Which it uses for threshing the sea like a flail, Which nobody can deny."

Songs and Verses by "An Old Contributor to Maga." p. 3 . 
now-a-days than it was in the hunting stage; and thus the prevalence of shortsightedness, so far as it cannot be accounted for by what takes place in the individual life-time, does not compel us to suppose that it has been produced by the hard study of past generations "poring over miserable books." At least the cautious verdict with regard to the transmission of the effects of use and disuse appears to be "not proven."

Mr. Wallace even rejects Darwin's theory of sexual selection, except in so far as it consists merely in the struggle between males and can therefore be resolved into one aspect of natural selection. ${ }^{1}$ So that no one could apply the theory of natural selection in a more complete and thorough-going way than Mr. Wallaceuntil he comes to the middle of his very last chapter. He fully accepts "Mr. Darwin's conclusion as to the essential identity of man's bodily structure with that of the higher mammalia, and his descent from some ancestral form common to man and the anthropoid apes"; but, when Darwin goes on to derive the moral nature and mental faculties of man

1 Daruinism, pp. 274, 283, 296. 
from their rudiments in the lower animals in the same manner and by the action of the same general laws as his physical structure, Mr. Wallace refuses to follow him. He holds that there is a "spiritual world," and that just as the glacial epoch supervened on the geologic causes previously in operation, so an "influx" from this spiritual world has produced man's moral sense, his mathematical, artistic and metaphysical faculties. ${ }^{1} \quad$ He considers himself driven to this supposition because he believes that these faculties cannot be accounted for by natural selection. Yet, after saying this, Mr. Wallace declares at the very end of his book that "the Darwinian theory, even when carried out to its extreme logical conclusion, not only does not oppose, but lends a decided support to a belief in the spiritual nature of man. It shows us how man's body may have been developed from that of a lower animal form under the law of natural selection; but it also teaches us that we possess intellectual and moral faculties which could not have been so developed, but must have had another origin; and for this origin we can only find an adequate cause in

I Ioid. p. 463 ; comp. p. 476 . 
the unseen universe of Spirit."1 Now, however true Mr. Wallace's beliefs about the spiritual world may be, it does seem odd to say that they are a carrying out of the Darwinian theory "to its extreme logical conclusion." One has heard of the young officer who said that Aldershot was a very nice place-to get away from, and of the schoolboy (was he Irish?) who defined sugar as "what makes your tea so nasty when you don't put any in "; and so we may say that the Darwinian theory supports Mr. Wallace's views, when he gets away from it, and when it is not applied to mental and moral evolution. This "spiritual world," which is postulated in order to account for the moral sense and the higher mathematics, is also to serve as an explanation of " the marvellously complex forces which we know as gravitation, cohesion, chemical force, radiant force and electricity, without which the material universe could not exist for a moment in its present form, and perhaps not at all, since without these forces, and perhaps others which may be termed atomic, it is doubtful whether matter itself could have any existence. And still more surely can 
we refer to it those progressive manifestations of Life in the vegetable, the animal and manwhich we may classify as unconscious, conscious and intellectual life-and which probably depend upon different degrees of spiritual influx."' Now, if gravitation, cohesion, etc., are the spiritual world, the ordinary man may well ask, "Where is the non-spiritual world?" and an idealist philosopher, where such can be found, will echo the question in a slightly different tone. Nobody denies that gravitation, chemical affinity, life, consciousness, intelligence, represent an ascending scale. But if the word "spiritual" be extended to the lowest of them, does this mean anything very different from extending the word "material" to the highest of them? There is, indeed, a difference between naming the ultimate principle of the universe from the higher end of the scale or from the lower; but it is a difference in ontological theory and not on a question of physical causation, with which alone the biologist, as such, has to deal.

Leaving this matter for the present, let us see what reasons Mr. Wallace has for rejecting

1 Ibid. p. 476. 
natural sclection as an explanation of the moral and intellectual nature of man. At first sight one is rather startled by the fact that, in order to prove that these are not derived from the rudiments of them in the lower animals, MIr. Wallace takes, not some characteristic that seems to belong to all men and no animals-a characteristic such as Professor Max Müller considers language to be-Mr. IVallace takes the mathematical, musical and artistic faculties, which, as he himself insists, are to be found only in a very small number of human beings. According to the somewhat arbitrary statistics of the schoolmasters consulted by Mr. Wallace, only about I per cent. of the boys in an English public school "have any special taste or capacity for mathematical studies," and only about I per cent., again, "have real or decided musical talent." 1 The line of argument appears to be as follows: (I) These faculties, not being useful to man in the struggle for existence, could not have been developed by natural selection. (2) If they had been so developed, they would have been present among human beings with some approach to equality.

$$
1 \text { Ibid.pp. 470, } 47 \mathrm{I} \text {. }
$$




\section{\$2. THE EVOLUTION OF MORALITY.}

The question of the origin of the moral sense is put aside in Darwinism" as "far too vast and complex to be discussed" there; but some discussion of it cannot well be avoided, because it forms the best initial test of the adequacy or inadequacy of the theory of natural selection outside the merely biological domain. The late Professor Clifford's brilliant, but too brief, contribution to ethics contains a more thoroughgoing application of the theory of natural selection to moral ideas than is to be found even in Darwin's Descent of Man ; for Darwin, in rather hesitating fashion, was still inclined to admit the transmission of acquired habits. ${ }^{2}$ Natural selection is also the principle of explanation adopted in Mr. Leslie Stephen's Scicnce of Ethics, and, more explicitly still, in Mr. S. Alexander's Moral Order and Progress.

To put the matter very briefly: Man starts with social instincts of the same kind as are to be found developed in different degrees among

1 p. 462 .

2 E.g., p. 125 (edit. 2). "We may expect that virtuous habits will grow stronger, becoming perhaps fixed by inheritance." 
the lower animals - and when we say "instincts" it is as well to remember what Mr. IVallace himself has so emphatically pointed out with regard to the lower animals: "Much of the mystery of instinct arises from the persistent refusal to recognise the agency of imitation, memory, observation and reason as often forming part of it." 1 The social instincts of man cause him to live in groups; and the struggle for existence is carried on, not merely between individual and individual, but between group and yroup, this second type of struggle leading to a mitigation of the fierceness of the struggle within any particular group. Thus, it is to the advantage of a tribe to have as many capable fighting members as possible: they are no longer mere rivals for food, but comrades in pursuit of a common end. Those qualities that tend to the success of the tribe in its contests with other tribes are "selected" for survival, because the tribes that display opposite qualities fail and are destroyed. What promotes the welfare of the tribe is approved; what hinders it is condemned. "Conscience," as Clifford puts it, "is the tribal self." IVe must not, and

1 Darwinism, p. 442.

D.P. 
need not, suppose any deliberate reflection in a primitive stage. In conduct, as in other regions of Nature, variations take place "spontaneously"-i.c., they happen to take place-how, or why, they take place is, as yet, a matter of pure speculation. The favourable variations are selected-i.e., the unfavourable variations lead to the failure and extinction of the organisms which display them. It is the same principle of natural selection which applies to variations in structure and functions, in habits, in implements: useful variations are continually being "selected," prior to any deliberate reflection about the adaptation of means to ends. Thus, in the ethical sphere, we have a selection of types of conduct; and these, the product of natural struggle and not of reflection, are the earliest moral ideals. Now all this has been put, as clearly as possible, by Mr. IVallace himself, in his earlier work, Contributions to the Theory' of Natural Sclection (I870), pp. 31 2, 3 I 3 :-

"Capacity for acting in concert for protection and for the acquisition of food and shelter; sympathy, which leads all in turn to assist each other; the sense of right, which checks depredations upon our fellows; the smaller development of the combative and destructive propensities; self-restraint in present appetites; and that intelligent foresight which pre- 
pares for the future, are all qualities, that from their earliest appearance, must have been for the benefit of each community, and would, therefore, have become the subjects for natural selection. . . Tribes in which such mental or moral (jualities were predominant would, therefore, have an advantage in the struggle for existence over other tribes in which they were less developed, would live and maintain their numbers, while the others would decrease and finally succumb."

But for the evolution of morality it is not necessary that the struggle should always go so far as the extinction of all the individuals practising a hurtful custom. Successful types of custom are imitated, and the disappearance of injurious customs before their successful rival customs may take the place of the disappearance of the persons or tribes who practise the injurious customs. It is a further step, and a step that, more than anything else, marks the rise of civilisation out of barbarism, when deliberate reflection leads a group of human beings to change their customs in order to escape the penalties of suffering and extinction which come from a blind adherence to old customs that once promoted the well-being of the community, but in changed circumstances have now become hurtful. Natural selection does not cease to operate; but the conflict of ideas takes the 
place of the competition of animal organisms. Imitation and reflection impose a check ont he mere physical struggle for existence; but, according to this evolutionist theory of morality, they are themselves the product of natural selection, and not of a distinct cause; and in the effects which they produce upon customs and ideas, the principle of natural selection is not left behind, but applied in a new sphere.

The growth of morality implies, of course, an advance in brain development, by the elimination within each group of the inferior members, and, in the struggle between groups, of the inferior groups. Further, we must notice the immense acceleration of progress rendered possible by language; and Mr. Wallace does not seem to deny that the most complex of human languages differs only in degree from the sounds and gestures by which animals convey their feelings and emotions to one another. Language renders possible the transmission of experience irrespective of transmission by heredity. By means of language and of social institutions we inherit the acquired experience, not of our ancestors only, but of other races in the same sense of "inheritance" 
in which we talk of people inheriting land or furniture or railway shares. Language renders possible an accumulation of experience, a storing up of achievements, which makes advance rapid and secure among human beings in a way impossible among the lower animals. Indeed, might we not define civilisation in general as the sum of those contrivances which enable human beings to advance independently of heredity? Civilisation is healthiest when it works along with heredity. Mankind never becomes completely independent of the effects of heredity. And the highest civilisation falling to the inheritance of a decaying race will not prevent, and may even hasten its decay and extinction. On the other hand, though the race perishes, the civilisation need not be lost, but may be handed on to worthier and more capable heirs.

Consciousness, reflection, language, are all obviously advantages in the struggle for existence to the beings possessing them; and it is much the simplest hypothesis to ascribe the origin of all of them to natural selection, instead of postulating a mysterious intrusion from without. As Mr. Wallace himself says: 
"In a scientific inquiry a point which can be proved should not be assumed, and a totally unknown power should not be brought in to explain facts when known powers may be sufficient." 1 But once there, consciousness, reflection, language, carry human beings rapidly a long way from the point at which those animals were, among whom these variations first appeared. Mr. Wallace contends that the large brains of savages and the absence of hair from the greater part of the surface of the body are both inexplicable on the theory of natural selection. ${ }^{2}$ Big brains and bare backs are, he thinks, no advantage to the savage, and therefore cannot be the subjects of natural selection. Is that so? The hairless homo with only a gorilla's brain would obviously be at a disadvantage compared with the gorilla, and would therefore disappear; but the disadvantage of a hairless skin has been more than compensated by the greater size of the brain. The hairy covering has ceased to be a necessity, and therefore has not been selected; and natural selection has thus offered no impedi-

1 Contributions to the Theory of Vitural Selection, p. 205.

2 Ibid.p. 348 . 
ment to the probable operation of sexual selection (in Darwin's sense) in furthering its disappearance. Greater brain development has allowed the luxury of sexual selection to operate without fatal results to the race. In any case, the greater the brain power, the less the necessity of a hairy covering. Nay, the progress of a hairless race has been brought about by the very needs of clothing and shelter adapted to varying circumstances, but only where these needs could be met because of greater brain development. Thus the diffculties raised by Mr. Wallace with regard to these two differences between man and the animals taken separately, disappear when they are taken together.

Mr. Wallace himself ${ }^{1}$ argues that the power possessed by savages of travelling through trackless forests comes not from instinct but from the use of the perceptive and reasoning faculties. Does not that imply the requirement of very considerable brain power? The civilised man uses his slightly greater brain power in many different ways, and therefore fails where the savage succeeds, his observa1 Contributions to the Theory of Natural Selection, p. 207. 
tion and his memory of what he has perceived being much less exact. As to the fact that the hair has disappeared from the back of homo, but not completely from the chest, is not that correlated with the adoption of the erect position ? and that, again, with the differentiation of hands and feet? And the advantage in both these differences between man and the lower animals is to be found in the use of missiles and tools.

Mr. Wallace, in his treatment of the moral sense, raises the usual Intuitionist objections to Utilitarianism. He holds that "there is a feeling, a sense of right and wrong in our nature, antecedent to and independent of experiences of utility." 1 Now, it is just the application of the theory of natural selection in ethics that has removed the force of the Intuitionist objections to the pre-evolutionist Utilitarianism. It was easy enough to point out that men's moral judgments are not as a rule based on calculations of consequences, but are the result of unreflecting feeling. To the Evolutionist ethics this is no objection. The theory of natural selection makes

1 Contrinutions to the Theory of Natural Sclution, p. 354. 
it a necessity that those societies should survive in which the promptings of the tribal self have been most felt; and the mysterious "feelings" on which the Intuitionist falls back are thus accounted for. At the same time it is perfectly easy for the Evolutionist to explain why some virtues have been earlier recognised than others, and why the same acts have in different times and places been regarded as good or bad-standing difficulties to the Intuitionist. When reflection appears, however, a higher form of morality becomes possible; the useful-i.e., what conduces to the welfare of the social organism, is not recognised merely by the failure of those societies in which it is not pursued, but by deliberate reflection on the part of the more thoughtful members of the society. The utilitarian reformer reflects for his society, and anticipates and obviates the cruel process of natural selection by the more peaceful methods of legislative change. The theory of natural selection thus gives a new meaning to Utilitarianism. The beginnings of morality are explained, and Utilitarianism is thus saved from the reproach of being applicable only to highly developed races. And, 
secondly, the well-being of society, as the ethical end, is substituted for the individualist conception of a balance of pleasures and pains. "Happiness," says Professor Clifford, "is not the end of right action. My happiness is of no use to the community, except in so far as it makes me a more efficient citizen; that is to say, it is rightly desired as a means and not as an end." 1

Natural selection can be likewise applied to the explanation of the origin and development of social and political institutions, provided that sufficient account be taken of imitation and reflection, as procluced by natural selection and yet counteracting the merely animal struggle for existence; provided also it be recognised that an idea or institution may supplant another without the individuals concerned being necessarily killed off in the process. Natural selection operates in the highest types of human society as well as in the rest of the organic realm; but it passes into a higher form of itself, in which the conflict of ideas and institutions takes the place of the struggle for cxistence between individuals and races.

1 Lectures and Essay's, ii. p. I73. 


\section{§3. INTELLECTUAL EVOLUTION.}

The mathematical, the musical and the artistic faculties, the metaphysical faculty and "the peculiar faculty of wit and humour" are considered by Mr. Wallace to supply the strongest arguments for the insufficiency of natural selection to account for mental evolution. They are, he argues, of no use to savages, and yet men must have these faculties latent in them, because they appear, though in very different degrees, among civilised races. Now, in the first place, is it true that the mathematical faculty and the musical faculty are of no use to the lower races in their struggle for existence? Undoubtedly, the primitive savage who became abstracted over a mathematical problem, like Archimedes, would die of starvation, if he did not rather help to ward off the same calamity from wild beasts or other wild men; but the savage who could count more than five would have an advantage over his rivals who never got beyond the fingers of one hand; the mother who could not count her children would succeed in rearing fewer than the mother 
whose domestic arithmetic was always accurate; and the people who believed that two and two made five, whether on this planet or on that other feigned by John Stuart Mill, would be at a disadvantage in fighting with the people who had established the doctrine that two and two made four. Plato says that Agamemnon would have been a poor sort of general if he had not been able to count his own feet; and Mr. Wallace himself admits the military advantage possessed by the Romans in their engineering skill. An Archimedes, though perhaps less useful as a heavy-armed soldier than a stupider man, was certainly of service to his fellow-citizens in the carrying on of war.

Elementary arithmetic and elementary perceptions of spatial relations would undoubtedly be useful to men living even under the rudest conditions, and the brains capable of very simple mathematical thinking may well enough be the ancestors of brains capable of more complex processes, if the capacity has been accumulated by favourable combinations of parents occurring again and again. It is not difficult to account for the fact that mathematical genius of a high order is sporadic, and 
rare even amongst the most civilised peoples. Mathematical genius of a high order, not being useful to the individual or the tribe under rude conditions, nor even under more advanced con. ditions, has not been selected as a characteristic of the species homo (in the way in which the capacity for language has been); nor has it become the special characteristic of any marked division of mankind, like any particular racecharacteristic. Under rude conditions such high scientific capacity would even be injurious; under fairly settled conditions it ceases to be injurious, its possessor is under no great disadvantage, and thus under favourable conditions mathematics is cultivated. Senior Wranglers may not always be useful members of society; but the society that can produce mathematicians of the quality of the average Senior IVrangler is likely to have good stuff in it for success in the struggle with Nature and with other societies. We must remember also that, besides the inheritance of a brain, which by accumulated favourable combinations of ancestry is capable of high mathematical thinking, various other conditions are requisite for the proper development of this capacity. 
The art of writing, the Hindoo system of numerical notation, access to printed textbooks, the opportunity of going to Cambridge, are all conditions for the development of latent inherited mathematical capacity. On the other hand, suppose a man born even at the present day with the brains of a Newton (and perhaps with the feeble body of a Newton also), in the backwoods of Western America, he would probably prove a failure, unless he could turn his gifts to the purposes of commercial speculation: he would be very unlikely to become an eminent mathematician.

The same arguments will apply in the case of music. It is most certainly untrue that music has not been useful to tribes in their struggle for existence. The bard has been no inconsiderable factor in stimulating the courage and furthering the cohesion of human societies. "Let who will make the laws of a nation, let me make its ballads," said Fletcher of Saltoun; and if for "ballads" we put the more general term "songs," the truth is still more obvious. The Marseillaise and Die Wacht am Rhein count for a good deal in the successes of French and German armies. It was not in 
vain that, according to the legend (which expresses at least a general truth), the Lacedremonians received from Athens the lame schoolmaster, who inspired their drooping courage by his songs; nor that the militant Dorians in general understood the value of music. Music having established its social utility in this way, there can be no doubt that sexual selection (in Darwin's sense) would come in to help the preservation and increase of any musical talent that appeared. The bard would be among the first kind of man admired for some other quality than fighting power or skill in hunting, and therefore preferred as a mate. Would not Mr. Wallace's arguments against the utility of music apply equally to the songs of birds, and would he not be equally justified in inferring that the lark and the nightingale manifest, as certain of our poets have said, an influx from the spiritual world?

But, of course, a highly complex music, if it could have arisen among savages, would be of no use to them. In order that the great musician may appear, not only must there be the physical inheritance of a fortunate combination of musical qualities, but there must be 
sufficient leisure and civilisation to save this comparatively rare "variation" from being speedily extinguished; and he must appear among a people who inherit socially a suffcient musical notation and sufficiently complex musical instruments. Mr. Wallace's objections seem plausible in great measure because he isolates the different forms of intellectual and resthetic capacity, as if these could exist separately. The music of savages is the germ of the music of Beethoven; but the gap between them is filled by advance, not in music only, but in a vast number of other things.

As to what is quaintly called "the metaphysical faculty," it will be generally agreed that if a man in the Stone Age, instead of sending his flint arrows at something he could eat, had sat down to think how motion was possible, or how contradictory movements were united in his handling of the bow, he would, like his mathematical brother, have supplied the cave-bear with a dinner, and not vice vers $\hat{a}$. But what appears as metaphysics among races who have won leisure to reflect, and have cleveloped a complex language capable of expressing abstract ideas, had appeared long 
before as the mythopoic tendency. This, perhaps, should be called, in IVeismann's phrase, a "bye-product" of the human mind. Reflection about the adaptation of means to ends for the purpose of everyday life is undoubtedly useful to the savage; but reflection on these subjects makes reflection possible on other subjects also, subjects quite unprofitable at first, such as "What makes the thunder?" "Why is the sea salt?" "Why do the flowers come up in the spring-time?" and so on. And language, being useful for the communication of practical projects, serves also to hand down even "useless" myths and legends. Yet are they useless? They serve to cement the bond between man and man, and thus have not been crushed out in the struggle for existence till they come to be a direct hindrance to progress ; and then they disappear before the growth of scientific ideas, except where they linger on as old wives' fables or children's fairy tales. Yet the crudest mythology is primitive science and primitive philosophy.

"The peculiar faculty of wit and humour," which "appears sporadically in a very small percentage of the population," " is, we may

1 Darroinism, p. 472.

1). $P^{\prime}$. 
allow, not useful, except, indeed, in so far as saying clever things keeps people from doing foolish ones; and since wit is only a bye-product of a complex brain, and not a variation useful to the species, we can easily account for its sporadic appearance and for the fact that most men "joke wi' deeficulty." IVit can only exist where there is a general high average of brain power, which is useful. When life can be taken with some amount of ease, then, and only then, do this and the other bye-products set a chance and escape destruction.

\section{\$4. CONCLUSTON.}

Thus natural selection, which is a true cause, seems a perfectly adequate cause to account for the appearance of all those intellectual capacities of human nature; and, if social erolution be rightly understood, there is nothing contradictory to natural selection in the occasional appearance of very high forms of them. The spiritual world need not be summoned as a mysterious counterpart to the material world, intruding itself into the latter, wherever the scientific investigator finds a difficulty at first sight, or the person who is afraid of science 
finds a convenient place of refuge for threatened beliefs. If a spiritual principle is recognised in the universe, it must be recognised not in the exceptional, not in holes and corners, like those intramundane spaces in which Epicurus stowed away the gods; but a spiritual principle must be recognised everywhere, as the condition of our knowing a system of nature. And Mr. Wallace is perhaps on the way to a sounder philosophy when he speaks of even gravitation as "spiritual," and sees, though dimly, that mere matter can have no existence, than when he uses intuitionist arguments about the moral sense, and treats mathematics and music as miracles due to a spiritual influx pouring in like a glacier on the world which is known to the ordinary biologist. Not in an exceptional origin of certain rare human qualities, but in the nature of human thought, however originated, is to be found the true spiritual greatness of man; and in the achievements of the human spirit in the institutions of society, in art, in religion, in science, and in philosophy is to be read, if anywhere, the little we can read about the ultimate meaning of the universe. 

N.TTURAL SELECTION AND TIIE HISTORY OF INSTITUTIONS. 
THE words "Development" and "Evolu1 tion" fit the changing course of human institutions and ideas so well that it seems, and indeed is, nothing new to find them applied to history. But there has been a temptation to assume that the conceptions of biology can be transferred to the facts of society without the need of a critical investigation of their validity in this new sphere. And those who are enyaged in historical research regarding special periods or particular institutions are apt to resent the procedure of the proudly scientific sociologist, who simply labels large groups of facts, taken from different ages and countries, with some biological heading without having sone through the labour of investigating concrete details himself. It is so very easy to say "Evolution " instead of saying "History," and to use a few Darwinian phrases as keys to 
unlock all mysteries. We can understand the suspicions roused in the mind of the historical student. But he is a bold man who, in the name of science, calls himself an "Anti-evolutionist" in these days when even theologians are endeavouring to make peace with the conqueror: yet he is performing a useful function, keeping us from falling into a "dogmatic slumber," and forcing us to analyse the conceptions we employ.

I propose to examine very briefly some arguments against the applicability of evolutional theories to the study of social institutions, which have recently been put forward by an eloquent Hungarian scholar, Dr. Emil Reich, in a little book entitled "Graco-Roman Institutions," the precursor, I believe, of a larger work on the History of Civilisation. I am not here concerned with Dr. Reich's theories about the origin of Roman Law, a matter which must be left to specialists; nor shall I say anything here about his underlying philosophical principles, which seem to me to imply a disbelief both

${ }^{1}$ Graco-Roman Institutions from an Anti-erolutionist point of riew. Four lectures delivered lefore the University of Oxford, by Emil Reich, Doct. Jur. : Oxford, I 890. 
in civilisation and in history.' I have to clo only with those pages in which he attacks the cvolution theory: Furthermore, I am not yoing to deal with "differentiation" and "intesration," the "homogeneous" and the "heteroyeneous," or any of the rest of Mr. Herbert Sipencer's antithetical formulix. I shall consider only "the concepts of Darwinism," to which, fortunately for my purpose, Dr. Reich limits his remarks.

Let me then take the factors required by the theory of natural selection, and see in what sense, if in any, they are applicable to society. 'These are variation, haredity', struggle for existence.

§ 2. "VARIATION."

In the biological sphere the laws of variation are still to a great extent wrapped in "profound mystery" and the subject of ingenious speculations. When, therefore, some

${ }^{1}$ Dr. Reich quotes with approval the dictum of Schopenhauer: "He who has read Herodotus has read all history, the rest being variations on an old theme"-a curious preliminary to a History of Cirilisation. What would the reader of Herodotus learn about Roman law? 
institution, or practice, or idea is called a "variation" by an evolutionist, the historian seems to have good ground for his complaint that nothing is thereby explained, that we are merely giving a name to the fact and leaving it as much a mystery as before. ${ }^{1}$ Yet, if we fully recognise that to say something is a "spontaneous variation" is only to declare our ignorance of how it came about, no harm is done: and it is well to be modest and confess our ignorance sometimes, though of course there is no special merit in the mere use of the Darwinian phrase. "Instead of begging incipient 'variations,' and leaving the explanation of their rise entirely unattempted, the student of institutions has to insist on nothing more uncompromisingly, than on the cxplanation of what Darwinists call "variations'" (p. 68). An explanation, certainly, if possible ; but when we cannot get one, we must go without. And what does Dr. Reich understand by an explanation? I quote a passage from the next page :-

${ }^{1}$ For the theory of natural selection it is, of course, not necessary that the causes of a variation should be known. If the variation is a fact, that is all that is needed. 
"Roman law offers, as we saw, the 'variation' of a civil law saturated with elements of criminal law. The causes of this variation are perfectly clear to the careful student of Roman institutions. It was the necessary check of a constitution that was built and erected on the strict morality of a few citizens" (p. 6q).

Dr. Reich does not explain how the variation arose: he only explains how the variation proved advantageous to the society in which it appeared, and so came, in Darwin's phrase, to be "selected," because it made Rome more successful than other communities in the struggle for existence. Dr. Reich claims (p. 67) to have proved that the Romans " did not 'evolve' their law out of rudimentary" 'variations' aided by 'natural selection in the struggle for life.", But, according to what he says on p. 69, the very thing he has proved is that Roman law was evolved by natural selection. He has not used the phrase; but, what is more important, he has applied the principle. If we may adopt the convenient Aristotelian term, Dr. Reich gives the "final cause," the "what for?" the "good" of an insti-

I I suppose Dr. Reich means "variations which are rudiments." 
tution: he does not give its "efficient cause," he does not explain how the first germs of the institution came into being, any more than an evolutionist who uses the phrase "spontaneous. variation."

In the case of the higher plants and animals, an undoubted cause of variation is scx. It is almost universally conceded that where two parents are needed, instead of one, there is a new combination of elements and a consequent possibility of variation at every step in descent. To produce the same apple we have to avoid sexual reproduction; seedlings mean the likelihood of new varieties. Direct action of the environment is an undoubted cause of variation in protozoa; whether it also affects specics produced by sexual reproduction is the controversy of the day among biologists. ${ }^{1}$ (Of course it affects all individuals.)

Now does anything correspond to "sex" and to "the direct action of the environment" in the case of societies, institutions, customs?" The environment most certainly does act upon races in determining their mode of life. Geographical conditions-mountains, plains or sea.

1 See above, pp. 42, SS. 
climate, the fauna and flora of the district, are all causes of variations. The change produced in the English race by America and Australia is a good instance. ${ }^{1}$ Whether and in what way the effects of climate, etc., on the physical organism are directly transmitted by heredity is, of course, part of controversy just referred to. Natural selection produces such an adaptation of the physical oryanism as is necessary to survival, i.c., types of physique that are not adapted to the new conclitions die out, and so the more suitable types are constantly selected, and thus there may gradually arise a great deviation from the type which remains more or less persistent in the old surroundings. Whether, over and above this gradual change produced by natural selection, the very marked effects which take place in the inclividual's lifetime are transmitted to his posterity is, as we have said, as yet "not proven."

But does anything correspond to "sex" ? Here, of course would be a tempting opportunity for the political psychologist, like Bluntschli, ${ }^{2}$

${ }^{1}$ Cp. Sir Chas. Dilke, Froblems of Greater Britain, ii. p. 579.

2 Theory of the Statc, Engl. Transl., p. 22. 
who tells us that the State is male, and the Church female (an opinion greatly supported, if not suggested, by the genders of the German words), or by those who speak of the Teutons as a masculine race, and the Celts as a feminine, and so on. But we need not spend time on these grammatical or poetical fancies. It is very generally admitted that sex, as a cause for variation, means mixture of elements; and thus its equivalent in social evolution is mingling of races and all that that brings with it. The Hellenic colonies in Asia and Africa supply abundant examples of the great variations brought about in character, institutions and ideas through the mixture of stocks. Our own race is another conspicuous example; and our language is a "variation" issuing from the marriage of a Low German speech with one of the children of Latin.

Apart altogether from the production of a "mixed race," there may be an intermingling of ideas and customs. Here we come upon the differences between organic and superorganic evolution. Human beings are not dependent on heredity alone. They may unconsciously or consciously imitate one another. At the 
Wwest stage there is the childish copying of strange modes of dress and habits, which is so common among savages and in fashionable society-doing a thing simply because others do it without any rason for it. Higher than this comes that learning from enemies which made the Romans struggling with the Carthaginians become a naval power through conscious imitation for a deliberate purpose. When they came in contact with the Greeks, their old customs began to vary, and they learnt much good and some evil. It is more than a mere figure of speech if we call Virgil's. poetry the offspring of a marriage between Italy and Greece. Similarly the Alexandrian culture was the child of East and West. Even temporary contact, whether of alliance or hostility, may produce lasting effects. The Crusaders brought back Saracenic culture to the western world. The Peninsular war introduced cigars into England; the Crimean war introduced cigarettes. These were new "variations" in England. 'The effect of contact is generally' some compromise-some product that is altowether new, the child, not of one parent, but of two, or of many. 
On the other hand, the legislators of ancient Lacedremon knew (like the Chinese) that, to keep institutions from varying, they must exclude foreign influences. Greek political idealists, who dreaded change above everything, feared the very neighbourhood of the sea. ${ }^{1}$ Here we have the equivalent of the identity of type which is maintained in plants where sexual reproduction is avoided.

The success of mixed races (provided the mixture be a good one), the advantage which has often come to a country even from conflict, are to a great extent to be explained by the additional chances of favourable variations which such races possess over those who are living on with the same stock of blood, institutions and ideas. "Protestant variations" at least imply intellectual progress. The absence of dissent and of controversy (which is the conflict and mingling of different ideas) means intellectual sterility. The Jews have remained the same race more than any other people; but they form no exception, for they have been dwellers in many lands, and whilst strengthened by the persecutions, they have been enriched by

${ }^{1}$ Cp. Plato, Lare's, 704, 705. 
the ideas, as well as by the trade, of many nations. Even the Roman Church, whilst boasting its unity and its permanence, has learnt much and gained much from conflict with its Protestant rivals.

When we explain a "variation" by referring it simply to race, we are not explaining it at all; and it is well to have this pointed out. To explain Roman institutions by the national character of the Romans is, as Dr. Reich says (p. I 7), just like explaining phenomena by means of "occult qualities." People in general are far too ready to refer the differences they find between nations to race-characteristics, instead of taking the trouble to look for other explanations first, in geographical conditions, institutions, past history and other external influences. Only when we have eliminated what is due to any or all of these causes (if we ever can do this), are we entitled to ascribe the residual phenomena solely to race-characteristics. English people have been very apt to explain all Irish discontents by saying that they result from the Irish, or, to make it look more scientific, from the "Celtic" character; this is more convenient than to read some very unpleasant D.P. 
pages of history and to trace the consequences of political oppression. An ethnological explanation is as yet no explanation, but only a re-statement of the problem to be solved.

Social variations may arise, then, from external influences, from intermixture or contact of races, from more or less conscious imitation. Conscious imitation because of some expected advantage already implies reflection, which is a further cause of variation among human beings. If customs or institutions are adopted not unconsciously, but because a reforming party have felt, and have convinced others, that such a change would be more advantageous to the community than to abide by the old customs, this is a variation resulting from reflection. Like all other variations, it will not become fixed as the characteristic of a type, unless it prove advantageous in some way or other, and for some time; it differs from other variations in being adopted expressly because of its anticipated utility.

We are indeed very apt to imagine that many variations, which have proved advantageous because of some purpose they serve, arose at first because of this advantage. We are often 
obliged for convenience to speak as if this were so; as, for instance, when we speak of "mimicry" in insects. This anticipatory mode of expression may cause no harm when applied to the lower animals, though even there it is apt to mislead the uninformed. In the case of human society it is always treacherous: it suggests the opposite exaggeration to that of those who see in human society nothing but mere natural processes and deny the place of deliberate reflection altogether. The distribution of powers which Montesquieu saw and admired in the English constitution was not the result of reflection on the part of any legislator; the distribution of powers which the founders of the American constitution adopted from Montesquieu's version of the English constitution was due to reflection.

\section{§ 3. "HEREDITY."}

By heredity in biological evolution is meant the fact that spontaneous variations tend to persist in the race, to be transmitted by descent. But human beings, besides sharing in this biological transmission of inherited 
characteristics, have also other modes of transmitting sentiments and customs; they are not dependent merely on heredity in the biological sense. They can "inherit" by means of language and institutions the experience of their ancestors, which would otherwise be lost and have to be acquired afresh-unless of course the Lamarckian hypothesis were true. A conspicuous example of the extent to which "social" inheritance may go, entirely unaided by biological inheritance, is to be found in the persistence of type and character in the Catholic clergy. There may even be less change in a celibate than in a hereditary official class. "Le clergé," says Montesquieu, " est une famille qui ne peut pas périr."

This capacity of social inheritance is the great advantage that mankind possesses over the brutes; and the greater perfection in the modes of transmitting experience constitutes the advantage of civilised over uncivilised races. I have already suggested a definition of civilisation as "the sum of those contrivances which enable human beings to advance independently of [biological] heredity." 1

1 See above, p. ror. 
In biological heredity structures are preserved and improved, if they are of distinct advantage to the species, through the operation of natural selection. If they cease to be of use, they may still persist as "survivals," unless they come to be of such decided disadvantage to the species that they disappear through natural selection. The same holds, mutatis mutandis, in sociological inheritance, and "survivals" may be found in abundance. Some of these may be retained because they serve a purpose very different from that served by the original variation from which they are descended.

Dr. Reich objects very strongly to the theory of "survivals" as applied to institutions and customs. "Our view of institutions" he says (p. 70) "being that all present institutions are kept in existence by present causes, we cannot adopt the evolutionist views of 'survivals.' Odd habits and ceremonies of our age, for instance, that are commonly explained on the assumption of their being 'survivals' of former ages, can all be accounted for by the working of present, if latent, causes." Here, as before, Dr. Reich recognises a "final cause," but 
refuses to recognise an "efficient" or "material " cause. Now, surely, a complete account of any institution would tell us not only what purpose that institution now serves, but what it came from; we need a theory of origin as well as an explanation of present value. But Dr. Reich's view of causation is peculiar in this respect. Thus he says (on p. I9): "The Americans continue to observe their written constitution, not because it was once written, but because they' are determined to revere it as their fundamental law. It is their merit, not that of Jefferson or Washington." Surely, if we are fully to understand the American constitution, we must take account of the makers of the constitution, its sources and the circumstances in which it came into existence, as well as of the present feelings of the lav-abiding citizens of the United States. There is, indeed, an unfortunate quarrel between the "historical" and the "analytic" methods of dealing with institutions. Voltaire ridiculed. Montesquieu for saying that the English constitution came from the forests of barbarous Germany. "I might as well say that the sermons of Tillotson and Smalridge were composed of old by 
Teutonic witches who divined the success of a war by the way in which the blood ran from the veins of a sacrificed captive." To say this may not seem quite so absurd to us as it did to Voltaire. A scientific student of religions might trace a connection between primitive magic and human sacrifice on the one hand and even tolerably advanced forms of Christian theology on the other. Professor Dicey does not think it necessary, like Mr. Freeman, to bring in the Landesgemeinden of Uri, the witness of Homer, the Germania of Tacitus, or the constitution of the IVitenagemót, in explaining the British constitution as that now is. ${ }^{1}$ The constitutional lawyer has a different problem from that of the historical antiquarian : and it is well to have it pointed out that we must explain an institution by considering not only what it came out of, but the way in which it now exists and the purposes it now serves. As we have said, a complete explanation requires both an investigation of origins (material and efficient causes) and an investigation of present nature and functions (formal and final causes). Let me take one other illustration of what I

I Dicey, Law of the Constitution, P1. viii. I 3 ff. (Ed. 3). 
mean, as it is a very excellent one. How are we to explain the absence of the English sovereign from Cabinet Councils? Of course it might be answered, and I imagine Dr. Reich would answer, that the present character of the English constitution requires that the sovereign should have no personal responsibility for the policy adopted by the ministry. But the explanation is surely incomplete, if we do not take account of the fact that George I. could not speak English, and consequently left his ministers to deliberate by themselves. Here was an "accidental" variation, which, proving favourable, gave rise to what now forms an essential principle of the constitution.

To come specially to " survivals." If we were to allege e.g. the use of Norman-French in giving the royal assent to acts of Parliament as an example of a survival, Dr. Reich, I suppose, would answer that this is kept up for the sake of maintaining the dignity of the Crown. Use plain English and the monarchy would tumble to pieces. Let us allow this to be the case: we know that it is generally risky to meddle with a very ancient piece of furniture. But surely a scientific explanation of this 
custom would require some reference to the Norman Conquest. Again, if we were to point to the shape of the academic dress worn in Oxford and Cambridge, Dr. Reich would answer that this is kept up for the sake of proctorial discipline. Granted that a uniform is kept up for the purpose; but why this particular uniform? A glance at an academic fashion-plate of the seventeenth century will supply an answer, so far as the square cap is concerned. There we see this cap in a shape exactly intermediate between the clerical berretta and its present form.

In scientific explanation it is not enough to show why some sort of thing exists or is done : we must explain, if we can, why it is just this and no other. The biologist does not merely say that colours of animals are useful to them, in the way of protection, etc.; if he says this, he is bound to show why this particular arrangement of stripes or spots is useful to this particular species in its particular environment; and if he calls anything a "survival," he must not be satisfied till he can show from what previous condition it is a survival. And so, it is not from a desire to take refuge in a vague 
general term, but because we are looking for concrete particular explanations, that we insist on the reality of "survivals" in institutions. The fact that a custom occasionally outlives the conditions which originally favoured its growth, needs no explanation. The tendency of human beings is to go on doing what they have been accustomed to do, unless there is a very strong reason for giving it up; and frequently even then. Natural selection does not eliminate disadvantageous customs in coherent human societies as rapidly as it eliminates disadvantageous characteristics among the lower animals. The disappearance of the circumstances, which produced any particular custom originally, make it easy, of course, $f_{C} r$ the custom to die out ; but, as a rule, some positive and considerable inconvenience is necessary to rouse people sufficiently to make them shake off any old habit. Occasionally something purely "accidental" ("accidental," of course, only in the same sense in which we speak of "spontaneous " variations) is sufficient to put an end to an old custom: thus the death of the holder of some antiquated office may give the occasion for discontinuing it. If an old custom dies out 
gradually, because it has ceased to have a meaning and a value, that is an illustration of the cessation of natural selection: if it becomes positively hurtful, it may lead to the destruction of the society that observes it, unless a wise change anticipates the operation of natural selection.

\$ 4. "THE STRUGGLE FOR EXISTENCE."

Most of what would fall to be said on this subject has already been discussed in the two preceding essays: ${ }^{1}$ and therefore a very brief summary of results must suffice here. First of all, the units engaged in that struggle which constitutes human history are not individuals only, but aggregates of individuals, such as tribes, races, nations, classes, sects. Secondly, apart from the struggle between individual and individual, between race and race, nation and nation, there is a struggle between institutions, languages, ideas. From these differences, in degree of complexity, between the biological and the sociological meaning of "struggle for existence" there follow two consequences: (I) The death of the individual organism is not ${ }^{1}$ Cp. pp. 13 ff., 97 ff. 
always necessary in "sociological" natural selection. "Evolutionist theories," says Dr. Reich, "draw most heavily on "death"; and so they must, because nature is "careless of the single life." And in the case of social organisms death is at work too; but the individuals of unsuccessful social organisms do not necessarily perish. The extinction of the individual is not always required for the triumph of an idea. ${ }^{1} \quad$ (2) On the other hand, ideas and institutions may outlive individuals and societies. Roman law has outlived all the Roman lawyers and the Roman Empire itself. Thus it is no argument whatever against the applicability of the doctrine of natural selection to social institutions to suggest, as Dr. Reich does, that an evolutionist historian must always hold that every later stage must be superior to the preceding, simply because it has "survived."

${ }^{1}$ Cp. S. Alexander, MToral Order and Progress, p. 330. "Punishment in man corresponds to the struggle of the dominant variety with other varieties. . . We punish in order to extirpate ideals which offend the dominant or seneral ideal. But in nature conflict means the extinction of individual animals: in punishment, it is sufficient that the false ideal is extinguished, and it is not necessary always that the person himself should be destroyed." 
"Survival of the fittest" is a very ambiguous phrase; and degeneration is often a condition of survival, instead of progress.

I have thus tried to show that the "concepts of Darwinism" are perfectly applicable to human society mutatis mutandis. The qualification is essential. The uncritical use of biological formula only leads to bad results in sociology and in practical politics. The genuinely scientific historian may never mention a single evolutionist catch-word, and yet be contributing to our knowledge of Evolution in its highest phase. The philosopher who saw a dialectic movement in human history and in the whole process of the universe was only reading back into the lower stages of Evolution what comes clearly to the surface in the highest, where the blind conflict of nature passes over into the conscious conflict of ideas. Progress comes only by struggle, though the struggle in its highest form may go on within the individual soul and may cause no death but the death of partial truths that have become errors, and of customs that have outlived their use. 
SOME PRESS NOTICES ON THE FIRST EDITION OF "DARWINISM AND POLITICS."

"This very able and interesting essay."-Glasgow Herald.

"Will be found suggestive throughout."-Pall Mall Gazctte.

"Considerable ingenuity as well as originality."-Whitehall Revier.

"Represents very well the attitude of many of the most earnest and cultured men at present guiding the destinies of the ancient Universities."-Manchester Examiner.

"Among the thoughtful books of I $\$ 89$, we can recommend this little volume."-True Thinker.

"A bright healthy picce of philosophy, with touches of pleasant humour."-Inquirer.

"Extremely suggestive and full of valuable ideas for the philosophic student of sociology."-Woman's Horld.

"One of the most suggestive books that we have met with for some time past, and we cannot commend it too highly to our readers."-Literary World.

"A timely criticism of the application of biological conceptions to social problems."-Political Science Quarterly.

"Short, crisp, argumentative, and practical."-Critic.

"Numerous as books on political and social economy now are, Mr. Ritchie's volume should certainly not be overlooked." -British Weekly. 


\section{SOCIAL SCIENCE SERIES.}

Scarlet Cloth, each 2s. 6 d.

1. WORK AND WAGES. Pruf. J. E. Thorold Rogers.

"Nothing that Professor Rogers writes can fail to be of interest to thought. ful penple." - Athenceun.

2. CIVILISATION: Its Cause and Cure. Edward CarPENTER.

"No passing piece of polemics, but a permanent possession."-Scottisk Revier.

3. QUINTESSENCE OF SOCIALISM. Dr. Sichaffle.

"Precisely the manual needed. Brief, lucid, fair, and wise."-Britis/ Wrectly.

4. DARWINISM AND POLITICS. D. G. Ritchie, M.A. (Oxon.) With an Appendix, showing its applications to (r) The Labour Question; (2) The Position of Women; (3) The Population Question. Second Edition, with two New Essays on Human Evolution.

"One of the most suggestive books we have met with."-Literary World.

5. RELIGION OF SOCIALISM. E. BELFORT BAX.

6. ETHICS OF SOCIALISM. E. BELFORT BAX.

"Mr. Bax is by far the ablest of the English exponents of Socialism.' I'estminster heview

7. THE DRINK QUESTION. Dr. Kate Mitchell.

"Plenty of interesting matter for reflection."-Graphic.

S. PROMOTION OF GENERAL HAPPINESS. Prof. M. Macmllan.

"A reasoned account of the most advanced and most enlightened utilitarian doctrine in a clear and readable form."-Scotsman.

9. ENGLAND'S IDEAL, Etc. Edward CaŔpenter.

"The literary power is unmistakable, their freshness of style, their humour, and their enthusiasm."-Pall Hall.

10. SOCIALISM IN ENGLAND. SinNey WEBb, LL.B.

"The best general view of the subject from the moderate Socialist side." Athenceum.

I1. PRINCE BISMARCK AND STATE SOCIALISM. IV. H. DAWSON.

"A succinct, well-digested review of German social and economic legislation since $1870 . "$-Saturday Reviez.

I2. GODWIN'S POLITICAL JUSTICE (ON PROPERTY). Edited by H. S. SALT.

"Shows Godwin at his best; with an interesting and informing Introduction."-Glasgow Herald.

13. STORY OF THE FRENCH REVOLUTION. E. BELFORT BAX.

"A trustworthy outline."-Scotsman.

14. THE CO-OPERATIVE COMMONWEALTH. LAURence Gronlund.

"An independent exposition of the Socialism of the Marx School."-Contemporary Revieze. 


\section{SOCIAL SCIENCE SERIES-continued.}

15. ESSAYS AND ADDRESSES. BERNARD BOSANQUEI, M.A. (Oxon.)

"Ought to be in the hands of every student of the Nineteenth Century spirit."-Echo.

"No one can complain of not being able to understand what Mr. Bosanquet means."-Pall Mall Gazette.

I6. CHARITY ORGANISATION. C. S. LOCH, Secretary to Charity Organisation Society.

"A perfect little manual."-Athenceum.

"Deserves a wide circulation,"-Scotsman.

17. THOREAU'S ANTI-SLAVERY AND REFORM PAPERS. Edited by H. S. SALT.

I8. SELF-HELP A HUNDRED YEARS AGO. G. J. Holyoake.

19. THE NEW YORK STATE REFORMATORY AT ELMIRA. Alexander Winter; with Preface by HaveLOCK ELLIS.

20. COMMON-SENSE ABOUT WOMEN. T. W. HIGGINSON.

2I. THE UNEARNED INCREMENT. IV. H. DAWSON.

22. OUR DESTINY. LAURENCE GRONLUND.

23. THE WORKING-CLASS MOVEMENT IN AMERICA. Dr. ED. and E. MARX AVELING.

24. LUXURY. EMILE de Laveleye.

25. THE LAND AND THE LABOURERS. Rev. C. W. Stubbs, M.A.

\section{IN ACTIVE PREPARATION ARE:-}

ORIGIN OF PROPERTY IN LAND. FUSTEL DE Coulanges. Edited by Prof. Ashley.

MALTHUS'S ESSAY ON POPULATION. Edited by A. K. DONALD.

THE CO-OPERATIVE MOVEMENT. BEATRICE POTTER. THE STUDENT'S MARX: An Abridgement of his "Capital."

LANGE'S THE LABOUR PROBLEM. Translated by Rev. J. Carter.

CRIME AND THE PRISON SYSTEM. W. DOUgLAS MORRISON.

PRINCIPLES OF STATE INTERFERENCE. D. G. RITCHIE, M.A.

THE EVOLUTION OF PROPERTY. PAUL LAFARGUE.

LONDON: SIVAN SONNENSCHEIN \& CO. 






\section{PLEASE DO NOT REMOVE} CARDS OR SLIPS FROM THIS POCKET

\section{UNIVERSITY OF TORONTO LIBRARY}

HM Ritchie, David George 


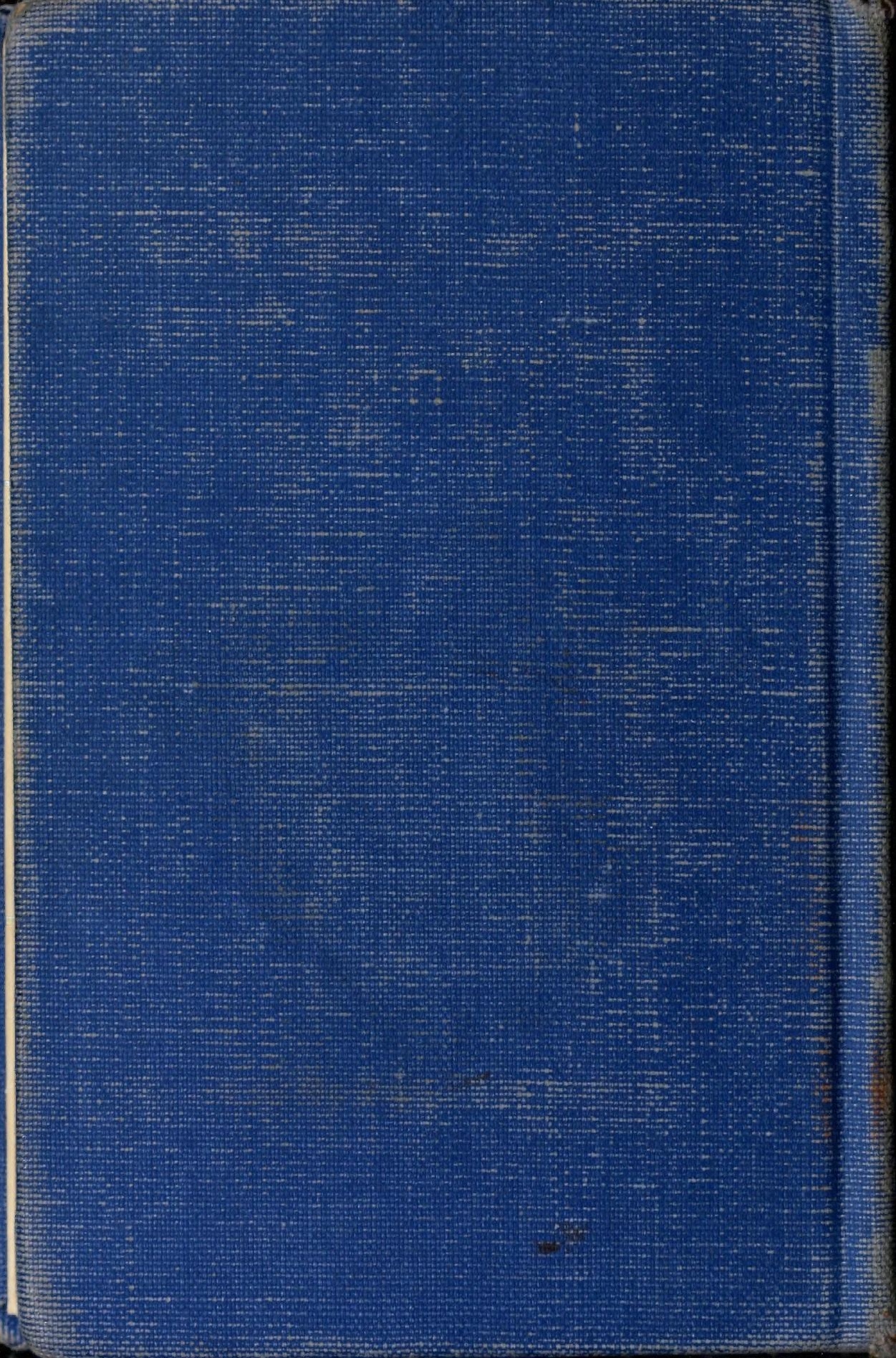

